\title{
The range and extent of the Vallesian Crisis (Late Miocene): new prospects based on the micromammal record from the Vallès-Penedès basin (Catalonia, Spain)
}

\author{
I. Casanovas-Vilar ${ }^{1 *}$, L.W. van den Hoek Ostende ${ }^{2}$, M. Furió ${ }^{1}$, P. A. Madern ${ }^{1,2}$ \\ ${ }^{1}$ Institut Català de Paleontologia Miquel Crusafont, Universitat Autònoma de Barcelona, 08193 Cerdanyola del Vallès, Spain. \\ ${ }^{2}$ Naturalis Biodiversity Center, PO Box 9517, 2300 RA, Leiden, The Netherlands. \\ e-mail addresses: isaac.casanovas@icp.cat (I.C.-V., *corresponding author); larsvandenhoekostende@naturalis.nl (L.V.H.O.); marc.furio@icp.cat (M.F.), \\ anneke.madern@naturalis.nl (P.A.M.)
}

Received: 23 April 2013 / Accepted: 3 December 2013 / Available online: 25 February 2014

\begin{abstract}
The Vallesian Crisis was initially recognized as a local event, which implied the extinction of certain rodent and artiodactyl genera coinciding with the early/late Vallesian boundary (at $9.7 \mathrm{Ma}$ ). Following works increased the range and extent of this event to encompass all Europe and involve a great number of mammal taxa. Here, we analyze the Vallesian rodent and insectivore record of the Vallès-Penedès basin (Catalonia, Spain), where the crisis was first recognized. We show that the quality of the record before the crisis is comparatively much better than afterwards so diversity appears inflated and extinction rates are overrated. Accordingly, we used inferred taxon ranges and rarefaction to calculate new diversity measures independent of sample size. These measures virtually eliminate the Vallesian Crisis, showing that diversity somewhat decreased during the earliest late Vallesian and soon recovered afterwards. This is because it cannot be discarded that several rare taxa, customarily said to have disappeared during the crisis, are in fact present. Amongst the rodents and insectivores, these taxa include genera that are generally rare and show a discontinuous record during the early Vallesian. These are presumed specialists adapted to humid forested environments such as flying squirrels, beavers or certain dormice, most of them being only recorded when the sample size is large enough. Alternatively, these genera may have been associated to very specific habitats which, for an unknown reason, are not sampled during the late Vallesian. Our results cast serious doubts on the very existence of the Vallesian Crisis suggesting that rather than an abrupt event a series of extinctions occurred during a longer time span. It has not been evaluated whether the same pattern is observed in the case of large mammals and in other areas. However, our results show that biases introduced by the quality of the record need to be taken into account when assessing the extent of the event.
\end{abstract}

Keywords: palaeodiversity, micromammals, Late Miocene, Vallès-Penedès basin, Catalonia, Iberian Peninsula

Resumen

La Crisis Vallesiense fue inicialmente definida como un fenómeno local que implicó la desaparición de ciertos géneros de roedores y artiodáctilos coincidiendo con el límite entre Vallesiense inferior y superior (hace $9.7 \mathrm{Ma}$ ). Trabajos posteriores ampliaron el ámbito y alcance de este evento hasta incluir toda Europa e implicar un gran número de taxones de mamíferos. En este trabajo analizamos el registro Vallesiense de roedores e insectívoros de la cuenca del Vallès-Penedès (Cataluña, España), donde la crisis fue reconocida por primera vez. Se muestra que la calidad del registro fósil con anterioridad a la crisis es comparativamente mucho mejor que la de después de modo que se magnifica la diversidad y se exageran las tasas de extinción. Por lo tanto, se ha utilizado rarefacción y se han inferido rangos estratigráficos a fin de calcular nuevas medidas de diversidad independientes del tamaño de la muestra. Estas medidas eliminan virtualmente la Crisis Vallesiense, mostrando que la diversidad disminuyó a principios del Vallesiense superior para recuperarse poco después a finales de esta edad. Esto es debido a que no podemos descartar que diversos taxones poco abundantes, normalmente citados como víctimas de la crisis, estuvieran de hecho presentes. Entre los roedores e insectívoros dichos taxones incluyen géneros que son generalmente raros y que muestran un registro discontinuo durante el Vallesiense inferior. Se trata de supuestos especialistas adaptados a ambientes boscosos húmedos tales como ardillas voladoras, castores o ciertos lirones, la mayoría de los cuales sólo se encuentran cuando el tamaño de la muestra es lo suficientemente grande. Alternativamente, estos géneros podrían haber estado asociados a hábitats muy específicos que por algún motivo no están siendo muestreados durante el Vallesiense superior. Nuestros resultados cuestionan seriamente la existencia de la Crisis Vallesiense y sugieren que en lugar de un evento abrupto podría tratarse de una serie de extinciones que habrían sucedido durante un período más largo. Queda pendiente de evaluación si el mismo patrón se observa en el caso de los grandes mamíferos y en otras áreas. No obstante nuestros resultados muestran que se deberían tomar en consideración las desviaciones introducidas por la calidad del registro al analizar el alcance de este evento. 


\section{Introduction}

The Vallesian stage was first proposed by M. Crusafont (1950) for the Late Miocene faunas of the Vallès-Penedès basin (Barcelona, Catalonia, Spain) characterized by the first appearance of the three-toed hipparionine horses (Hipparion s.1.). At that time, Hipparion (now split into several genera) was known to be a characteristic element of the Late Miocene faunas of Pikermi (Greece), which also included certain bovids, giraffids and other open-country mammals. The European Middle Miocene sites known to that date included $\mathrm{La}$ Grive and Sansan, both in France, which showed a completely different mammal assemblage, dominated by cervids and suids and characteristic of more humid and forested environments. The Vallesian assemblages were intermediate between both faunas, Hipparion and certain eastern immigrants (for example the giraffid Palaeotragus or the felid Machairodus) were present, but coexisted with Middle Miocene elements characteristic of forested environments. Crusafont (1950) noted that the final extinction of these forest-dwelling forms and the arrival of new eastern immigrants did not occur until the Late Pontian (= Turolian). The Vallesian faunas and environments would reflect that the changes that occurred during the Late Miocene were gradual (Crusafont, 1950).

Since then, Vallesian mammal assemblages have been recognized in Eurasia and Northern Africa and the use of the stage name is widespread (Mein, 1975; Lindsay and Tedford, 1990). The Vallesian was subdivided into early and late Vallesian, that later on Mein (1975) equaled to his Mammal Neogene Zones (MN) MN9 and MN10, respectively. At the same time, the Vallesian record in its type-area became progressively more complete, notably with the discovery of new sites and after the large scale excavation of major classical ones such as Can Llobateres in Sabadell (Crusafont, 1964). The latter site in particular has been excavated during several years and stands out as one of the most densely sampled localities of the European Miocene (for an account of older campaigns see Galobart et al., 2011; for the results of more recent ones see Begun et al., 1990; Moyà-Solà and Köhler, 1993, 1995, 1996, Alba et al., 2011a, 2011b).

With all these new data, Agustí and Moyà-Solà noted in the late 1980s and early 1990s that certain rodent and artiodactyl genera recorded during the early Vallesian (MN9) seemed to have disappeared by the late Vallesian (MN10) (Agustí, 1981; Agustí et al., 1984; Moyà-Solà \& Agustí, 1987). Whereas the Aragonian/Vallesian transition (that is the Middle/Late Miocene boundary) did not represent any remarkable change in the rodent assemblages, during the early/late Vallesian one most of the glirids and eomyids, together with some muroids (Megacricetodon, Eumyarion) seem to have disappeared. Amongst the artiodactyls certain bovids (Protragocerus, Miotragocerus), suids (Listriodon, Hyotherium, Parachleuastochoerus) and cervids (Euprox) went extinct. At the same time, some faunal elements typical of the Turolian (including Tragoportax, Microstonyx, Adcrocuta and Progonomys his- panicus) first appear at the early/late Vallesian boundary. It is interesting to note that in these early publications the authors did not refer to this event as a diversity crisis and restricted its geographical range to the Vallès-Penedès basin. However, in later works the severity of this event was emphasized (Agustí and Moyà-Solà, 1990, 1991; Moyà-Solà and Agustí, 1990). Furthermore, in Agustí and Moyà-Solà (1990), the paper that has become the seminal reference for the Vallesian Crisis, the authors broadened the geographical range of the event to encompass all of Europe. In the same work they conclude that the event was rapid and discuss a correlation with the climatic and paleogeographic evolution of Europe during the Late Miocene. Successive publications already have referred to the event as the 'Vallesian Crisis' (or sometimes as midVallesian Crisis or late Vallesian Crisis) and have added new taxa to the list of victims, such as the flying squirrels (Miopetaurista, Albanensia), the beavers (Chalicomys, Euroxeno$m y s$ ), certain carnivores (barbourofelids, amphicyonids), rhinoceroses (Lartetotherium and other genera), tapirs and the great ape Hispanopithecus (Agustí et al., 1997, 1999, 2003; Fortelius and Hokkanen, 2001). Fortelius et al. (1996) and Fortelius and Hokkanen (2001) noted that the drop in diversity affected mainly medium-sized mammals, both carnivores (mainly mustelids) and herbivores (small suoids, cervids and primates).

On the other hand, the study of other Iberian records, such as the densely sampled micromammal record of the Teruel basin (Van Dam, 1997; Van Dam et al., 2001), has shown that a number of extinctions occurred during the late Vallesian but over a longer time interval, from about 9.5 to $9.1 \mathrm{Ma}$ (Van Dam, 1997). The Crisis has not been recognized in Central Europe (Franzen and Storch, 1999; Casanovas-Vilar et al., 2005), where many forest-adapted taxa (cervids, amphycionids, tapirids) survived into the early Turolian (MN11). In the eastern Mediterranean (Greece, Turkey and nearby countries) the small mammal record does not record major extinctions (De Bruijn et al., 1996) and large mammal diversity increased continuously during the Vallesian, peaking at the early Turolian (Fortelius et al., 1996; Casanovas-Vilar et al., 2005). Therefore, there is still a debate on the geographical range and timing of the Vallesian Crisis, being either considered an abrupt event that may have affected the whole continent (Agustí and Moyà-Solà, 1990; Agustí et al., 1997, 1999, 2003; Fortelius and Hokkanen, 2001) or a series of extinctions restricted to southwestern Europe (De Bruijn et al., 1996; Casanovas-Vilar et al., 2005, 2010).

The causes of the Vallesian Crisis are even more controversial because the event does not coincide with major environmental perturbations, since the main climatic (Zachos et al., 2001) and vegetation (Mossbrugger et al., 2005) changes in Europe had already started by the Middle Miocene (between 17 and $15 \mathrm{Ma}$ ). Therefore, the Vallesian Crisis has been linked to a complex interplay of climatic and paleogeographic causes (Agustí and Moyà-Solà, 1990; Agustí et al., 1997, 1999, 2003). Those would have led to an increase of 
the temperature latitudinal gradient along Europe, whereas in the peri-Mediterranean regions they implied the development of marked rainfall seasonality that would have resulted in a more open and dry environment (Agustí et al., 1997, 1999; Van Dam and Weltje, 1999; Fortelius and Hokkanen, 2001; Böhme et al., 2008). However, Agustí et al. (2003) show the persistence of forested areas during the late Vallesian (at about $9.2 \mathrm{Ma}$ ) in the Vallès-Penedès, although deciduous trees define a great proportion of the assemblages. Therefore, these authors relate the Vallesian Crisis in the type area to an increase in temperature seasonality. Nonetheless, deciduous elements already were major constituents of the Middle Miocene forests of both Central Europe (Mossbruger et al., 2005) and the Iberian Peninsula (Barrón et al., 2010), as well as in coastal areas near the Vallès-Penedès (Gómez-Gras et al., 2001).
While the geographical extent of the Vallesian Crisis has been questioned by some authors, the existence of such event in the Vallès-Penedès seems beyond doubt. The quality of the Vallesian record in this basin has greatly increased during the previous two decades (see Agustí et al., 1997) and a high degree of dating accuracy has been attained for most of the sites (Garcés et al., 1996; Agustí et al., 1997; Casanovas-Vilar et al., 2011a). This allows examining Vallesian diversity dynamics for some groups in much more detail than during the 1980s and early 1990s. Furthermore, statistical procedures can be applied to assess how the uneven sampling of the Vallesian sites may affect our perception of diversity changes. J. Agustí, one of the 'discoverers' of the Vallesain Crisis, already noted that a re-evaluation of the event in its type-area should be attempted taking into account the quality of the record and the new data gathered during the 1990s
Fig. 1.- Geographical situation of the Vallès-Penedès basin (lower left corner) and situation of the main Vallesian magnetostratigraphical sections. Acronyms are as follows: $\mathrm{CC}=\mathrm{Can}$ Coromines: $\mathrm{CL}=$ Can Llobateres; $\mathrm{CR}$ $=$ Can Cormines; $\mathrm{FN}=\mathrm{Can}$ Fonollet; GL = Can Guilera; $\mathrm{GT}=$ Can Guitart; $\mathrm{H}=$ Hostalets de Pierola; LT = La Tarumba; MR = les Martines; $\mathrm{TF}=$ Torrent de Febulines; TNA $=$ Trinxera Nord Autopista; TSA = Trinxera Sud Autopista; VQ = Viladecavalls. See also figure 2 .

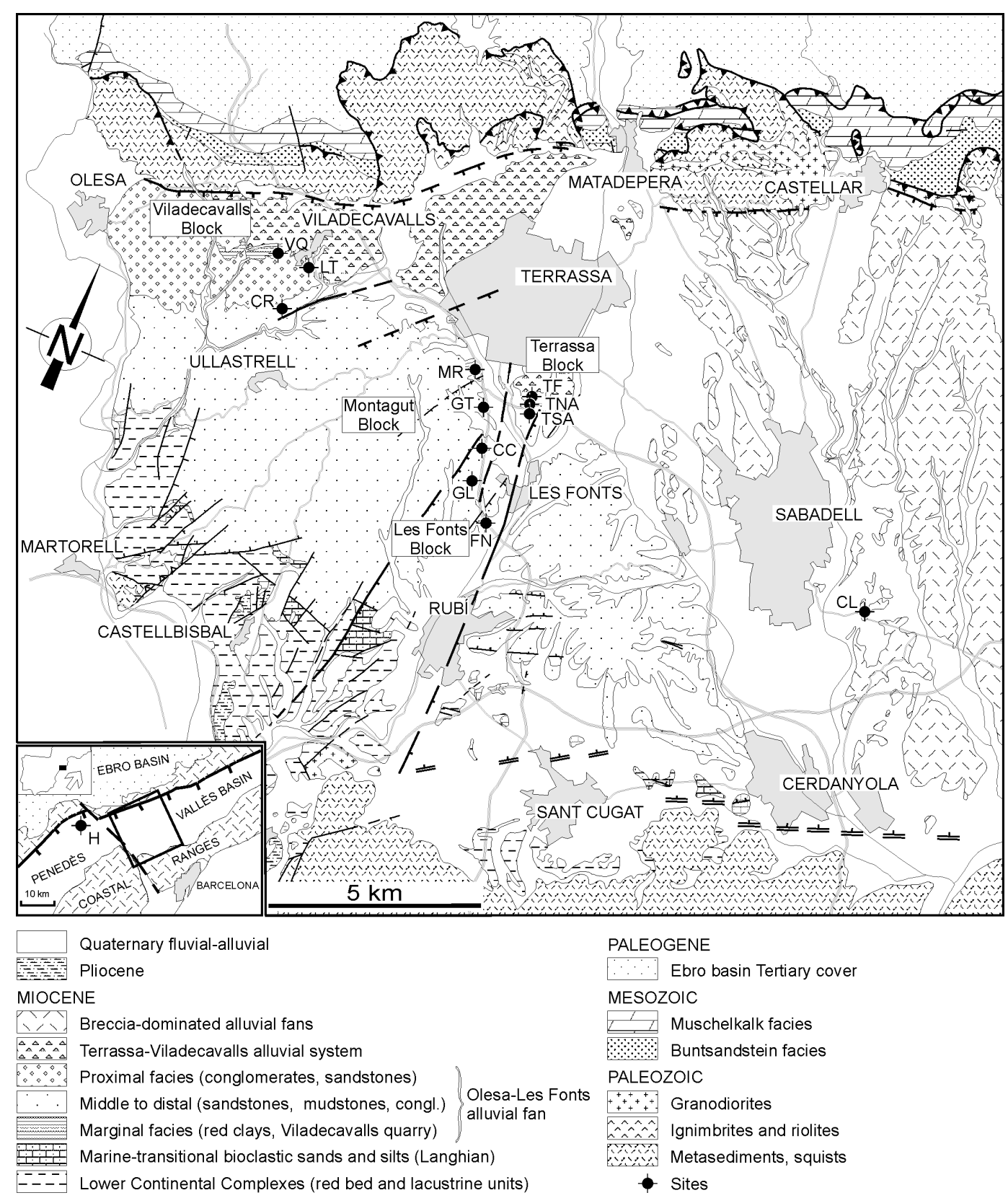




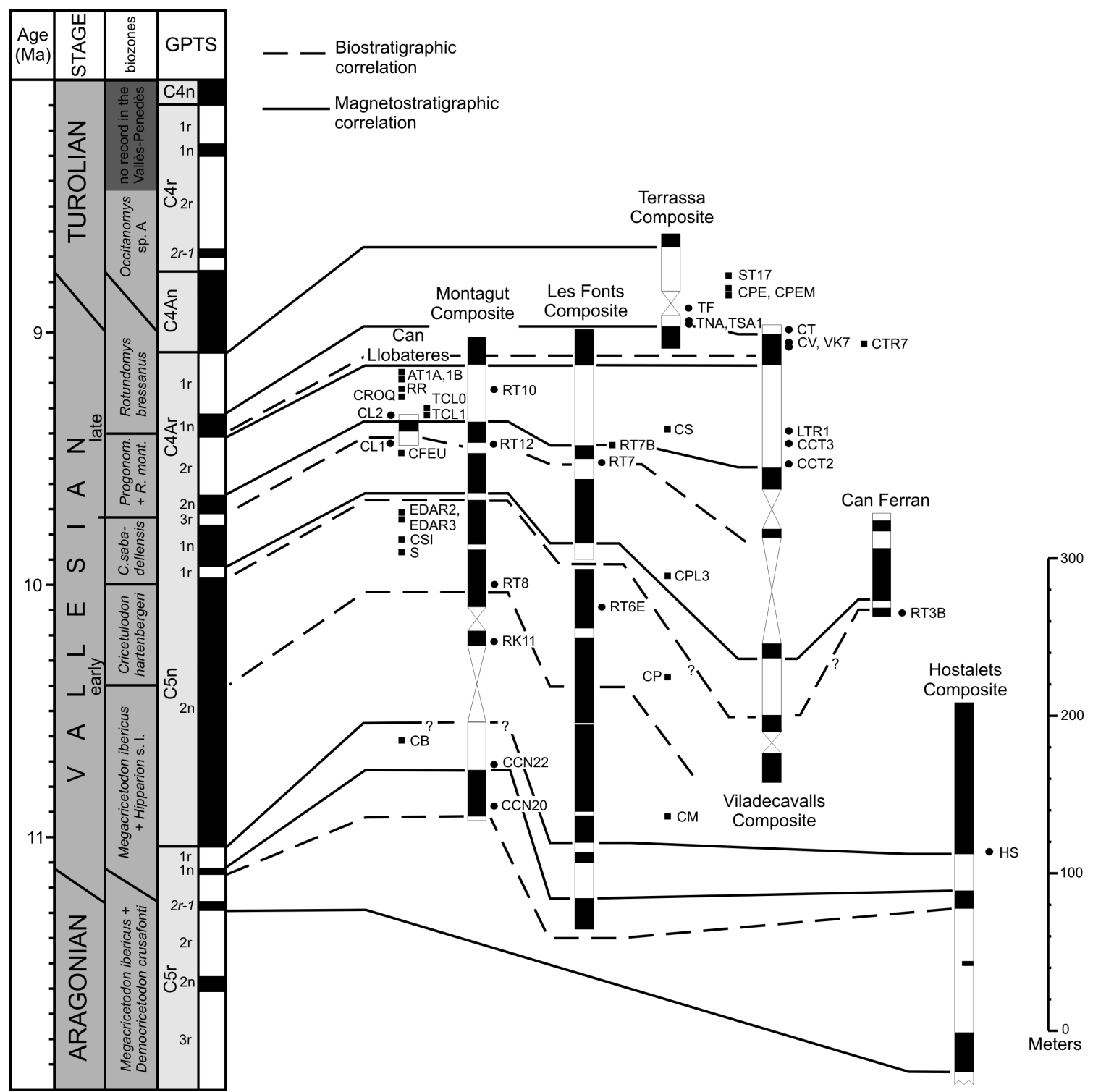

Fig. 2.- Chronological framework with Vallesian magnetostratigraphical sections and localities. Sections are represented by vertical bars showing the local magnetic polarity and are correlated to the Geomagnetic Polarity Time Scale (GPTS). Dots represent the sites within a magnetostratigraphic section and are indicated next to it. Localities correlated by means of biostratigraphy are indicated with a square. Each one is assigned to a unique local biozone. The age of geomagnetic chron boundaries is taken from Ogg and Smith (2004) whereas the stratigraphic position of the different localities is taken from Garcés (1995) for the sites in the Vallès sector of the basin and from Moyà-Solà et al. (2009a) for the ones from the Hostalets de Pierola area. The local biozonation for the Vallès-Penedès basin is after Casanovas-Vilar et al. (2011a). The composite section of Montagut includes the local sections of Can Guitart 1, 2 and 3, besides les Martines; les Fonts includes Can Fonollet, Can Guilera and Creu Conill; Viladecavalls includes Bòvila de Ceràmiques Viladecavalls, Can Coromines and la Tarumba; Terrassa includes Torrent de Febulines; and that of Hostalets includes Riera Claret and Abocador de Can Mata. For locality acronyms see Table 1.

(pers. com. to ICV). This is the main goal of this work, in which we further discuss the timing, range and extent of this biotic event.

\section{Material and methods}

\subsection{Age of localities and assignment to temporal intervals}

The temporal ordination of faunal events as well as the calculation of sampling probability and inferred taxon ranges (see section 2.3) requires assigning an absolute age to each locality. For many localities, this absolute age can be interpolated on the basis of the stratigraphic position of the locality in the local magnetostratigraphic sections (Figs. 1-2). The interpolation must be done between two points of known age, such points being the magnetic polarity changes in the section that correspond to geomagnetic chron boundaries. Then we used the formula of Barry et al. (2002) to assign an absolute age to the localities:

$$
A g e=U A g e+\left(\frac{(L A g e-U A g e)}{T} \cdot S D\right)
$$




\begin{tabular}{|c|c|c|c|c|c|c|c|c|c|}
\hline locality & $\begin{array}{l}\text { magnetostrati- } \\
\text { graphic section }\end{array}$ & $\begin{array}{l}\text { geomagnetic } \\
\text { chron }\end{array}$ & local biozone & acronym & $\begin{array}{l}\text { assigned age } \\
\text { (Ma) }\end{array}$ & $\begin{array}{l}\text { maximum } \\
\text { age (Ma) }\end{array}$ & $\begin{array}{l}\text { minimum } \\
\text { age }(\mathrm{Ma})\end{array}$ & $\begin{array}{l}\text { sample } \\
\text { size }\end{array}$ & $\begin{array}{l}\text { genera } \\
\text { richness }\end{array}$ \\
\hline Arrahona tèxtil $1 \mathrm{~A}$ & - & - & Progonomys $+R$. montisrotundi & AT1A & - & 9.70 & 9.40 & 8 & 3 \\
\hline Arrahona tèxtil $1 \mathrm{~B}$ & - & - & Progonomys $+R$. montisrotundi & AT1B & - & 9.70 & 9.40 & 1 & 1 \\
\hline Autopista Rubí-Terrassa 10 & LM & C4Ar.2r & Progonomys $+R$. montisrotundi & RT10 & 9.51 & - & - & 1 & 1 \\
\hline Autopista Rubí-Terrassa 12 & LM & C4Ar.3r & Progonomys $+R$. montisrotundi & RT12 & 9.73 & - & - & 10 & 2 \\
\hline Autopista Rubí-Terrassa 3B & $\mathrm{FE}$ & C $5 n .2 n$ & C. hartenbergeri & RT3B & 10.01 & - & - & 36 & 6 \\
\hline Autopista Rubí-Terrassa 6E & GUI & C $5 n \cdot 2 n$ & C. hartenbergeri & RT6E & 10.10 & - & - & 12 & 8 \\
\hline Autopista Rubí-Terrassa 7B & - & - & Progonomys $+R$. montisrotundi & RT7B & - & 9.70 & 9.40 & 13 & 2 \\
\hline Autopista Rubí-Terrassa 7C & $\mathrm{CCN}$ & C4Ar.3r & Progonomys $+R$. montisrotundi & RT7 & 9.74 & - & - & 167 & 9 \\
\hline Autopista Rubí-Terrassa 8 & CG2 & C $5 n .2 n$ & C. hartenbergeri & RT8 & 10.60 & - & - & 8 & 6 \\
\hline $\begin{array}{l}\text { Autopista Rubí-Terrassa } \\
\text { Km } 11\end{array}$ & CG2 & C5n.2n & M. ibericus + Hipparion s.1. & RK11 & 10.98 & - & - & 6 & 6 \\
\hline $\begin{array}{l}\text { Autopista Sabadell-Terrassa } \\
\mathrm{Km} 17\end{array}$ & - & - & R. bressanus & ST17 & - & 9.40 & 8.70 & 2 & 1 \\
\hline Camí de Can Tarumbot 2 & $\mathrm{COR}$ & C4Ar.2r & Progonomys $+R$. montisrotundi & $\mathrm{CCT} 2$ & 9.60 & - & - & 27 & 3 \\
\hline Camí de Can Tarumbot 3 & $\mathrm{COR}$ & C4Ar.2r & Progonomys $+R$. montisrotundi & СCT3 & 9.64 & - & - & 5 & 2 \\
\hline Can Casablanques & - & - & Progonomys $+R$. montisrotundi & CS & - & 9.70 & 9.40 & 5 & 5 \\
\hline Can Feu 1 & - & - & C. sabadellensis & CFEU1 & - & 9.90 & 9.70 & 6 & 4 \\
\hline Can Feu 2 & - & - & C. sabadellensis & CFEU2 & & 9.90 & 9.70 & 32 & 6 \\
\hline Can Flaquer/Can Mata III & $\mathrm{RCL}$ & C5r.1r & M. ibericus + Hipparion s.l. & HS & 11.12 & - & - & 233 & 6 \\
\hline Can Llobateres 1 & CL & C4Ar.3r & C. sabadellensis & CL1 & 9.78 & - & - & 1263 & 27 \\
\hline Can Llobateres 2 & CL & C4Ar.2r & Progonomys $+R$. montisrotundi & CL2 & 9.64 & - & - & 21 & 8 \\
\hline Can Llobateres $2 \mathrm{C}^{1}$ & $\mathrm{CL}$ & C4Ar.2r & Progonomys $+R$. montisrotundi & CL2D & 9.64 & & & 8 & 4 \\
\hline Can Llobateres $2 \mathrm{D}^{1}$ & $\mathrm{CL}$ & C4Ar.2r & Progonomys $+R$. montisrotundi & CL2D & 9.64 & - & - & 8 & 4 \\
\hline Can Missert & - & - & M. ibericus + Hipparion s.l. & $\mathrm{CM}$ & - & 11.10 & 10.60 & 100 & 10 \\
\hline Can Pallars de Llobateres 3 & - & - & C. sabadellensis & CPL3 & - & 9.90 & 9.70 & 357 & 19 \\
\hline Can Perellada & - & - & R. bressanus & $\mathrm{CPE}$ & - & 9.40 & 8.70 & 21 & 1 \\
\hline Can Perellada & - & - & R. bressanus & CPE & - & 9.40 & 8.70 & 21 & 1 \\
\hline Can Perellada M & - & - & R. bressanus & CPEM & - & 9.40 & 8.70 & 3 & 1 \\
\hline Can Poncic & - & - & C. hartenbergeri & $\mathrm{CP}$ & - & 10.40 & 9.90 & 464 & 20 \\
\hline Can Roqueta & - & - & Progonomys $+R$. montisrotundi & CROQ & - & 9.70 & 9.40 & 20 & 5 \\
\hline Can Simeó & - & - & C. hartenbergeri & CSI & - & 10.40 & 9.90 & 2 & 1 \\
\hline Can Trullàs 7 & - & - & Progonomys $+R$. montisrotundi & CTR7 & - & 9.70 & 9.40 & 1 & 1 \\
\hline Can Turu & CT & C4Ar.1r & R. bressanus & CT & 9.32 & - & - & 6 & 1 \\
\hline Castell de Barberà ${ }^{2}$ & - & - & M. ibericus + Hipparion s.l. & $\mathrm{CB}$ & 10.55 & - & - & 787 & 23 \\
\hline Ceràmiques Viladecavalls & $\mathrm{VC}$ & C4Ar.1n & R. bressanus & $\mathrm{CV}$ & 9.33 & - & - & 13 & 3 \\
\hline Creu Conill 20 & CG1 & C5r.1n & M. ibericus + Hipparion s.l. & $\mathrm{CCN} 20$ & 11.14 & - & - & 59 & 4 \\
\hline Creu Conill 22 & CG1 & C5r.1r & M. ibericus + Hipparion s.1. & $\mathrm{CCN} 22$ & 11.05 & - & - & 458 & 9 \\
\hline Estació Depuradora Aigües Residuals 2 & - & - & C. hartenbergeri & EDAR2 & - & 10.40 & 9.90 & 134 & 9 \\
\hline Estació Depuradora Aigües Residuals 3 & - & - & C. hartenbergeri & EDAR3 & - & 10.40 & 9.90 & 80 & 12 \\
\hline La Tarumba 1 & LTR & C4Ar.2r & Progonomys $+R$. montisrotundi & LTR1 & 9.56 & - & - & 6 & 3 \\
\hline Riu Ripoll & - & - & Progonomys $+R$. montisrotundi & RR & - & 9.70 & 9.40 & 29 & 5 \\
\hline Santiga & - & - & C. hartenbergeri & $\mathrm{S}$ & - & 10.40 & 9.90 & 125 & 12 \\
\hline Torrent de Febulines & $\mathrm{TF}$ & C4Ar.1r & R. bressanus & $\mathrm{TF}$ & 9.12 & - & - & 35 & 11 \\
\hline Torrent de Febulines $3^{3}$ & $\mathrm{TF}$ & C4Ar.1r & R. bressanus & TF3 & 9.12 & - & - & 30 & 6 \\
\hline Torrent de Febulines $4^{3}$ & $\mathrm{TF}$ & C4Ar.1r & R. bressanus & TF4 & 9.12 & - & - & 20 & 7 \\
\hline Torrent de Febulines $\mathrm{M}^{3}$ & $\mathrm{TF}$ & C4Ar.1r & R. bressanus & TFM & 9.12 & - & - & 20 & 7 \\
\hline Trinxera Can Llobateres 0 & - & - & Progonomys $+R$. montisrotundi & TCL0 & - & 9.70 & 9.40 & 199 & 9 \\
\hline Trinxera Can Llobateres 1 & - & - & Progonomys $+R$. montisrotundi & TCL1 & - & 9.70 & 9.40 & 273 & 10 \\
\hline Trinxera Nord Autopista & $\mathrm{TF}$ & C4Ar.1r & R. bressanus & TNA & 9.40 & - & - & 87 & 8 \\
\hline Trinxera Nord Autopista $2^{4}$ & $\mathrm{TF}$ & C4Ar.1r & R. bressanus & TNA2 & 9.40 & - & - & 28 & 2 \\
\hline Trinxera Sud Autopista 1 & $\mathrm{TF}$ & C4Ar.1r & R. bressanus & TSA1 & 9.38 & - & - & 4 & 1 \\
\hline Trinxera Sud Autopista $2^{5}$ & $\mathrm{TF}$ & C4Ar.1r & R. bressanus & TSA2 & 9.38 & - & - & 66 & 9 \\
\hline Trinxera Sud Autopista $3^{5}$ & $\mathrm{TF}$ & C4Ar.1r & R. bressanus & TSA3 & 9.38 & & & 35 & 6 \\
\hline Viladecavalls Km 7 & $\mathrm{VC}$ & C4Ar.1n & R. bressanus & VK7 & 9.33 & - & - & 1 & 1 \\
\hline
\end{tabular}

1 Can Llobateres 2C and 2D are laterally equivalent to Can Llobateres 2.

2 The assigned age of Castell de Barberà has been interpolated taking into account the stratigraphic distance between this site and Can Llobateres 1 (see text for details).

3 Torrent de Febulines 3,4 and M are laterally equivalent to Torrent de Febulines.

4 Trinxera Nord Autopista 2 is laterally equivalent to Trinxera Nord Autopista.

5 Trinxera Sud Autopista 2 and 3 are laterally equivalent to Trinxera Sud Autopista 1.

Table 1. Locality database. The acronyms for magnetostratigraphic sections are as follows: Can Ferran (FE); Can Turu (CT); Can Guitart 1, 2 and 3 (CG1, CG2, CG3); les Martines (LM); Can Fonollet (FO); Can Guilera (GUI); Creu Conill (CCN); Bòvila de Ceràmiques Viladecavalls (VC); Can Coromines (COR); la Tarumba (LTR); Torrent de Febulines (TF); Riera Claret (RCL) and Abocador de Can Mata (ACM). Sample size refers to the total number of rodent and insectivore cheek teeth. See section 2.1 for details. 


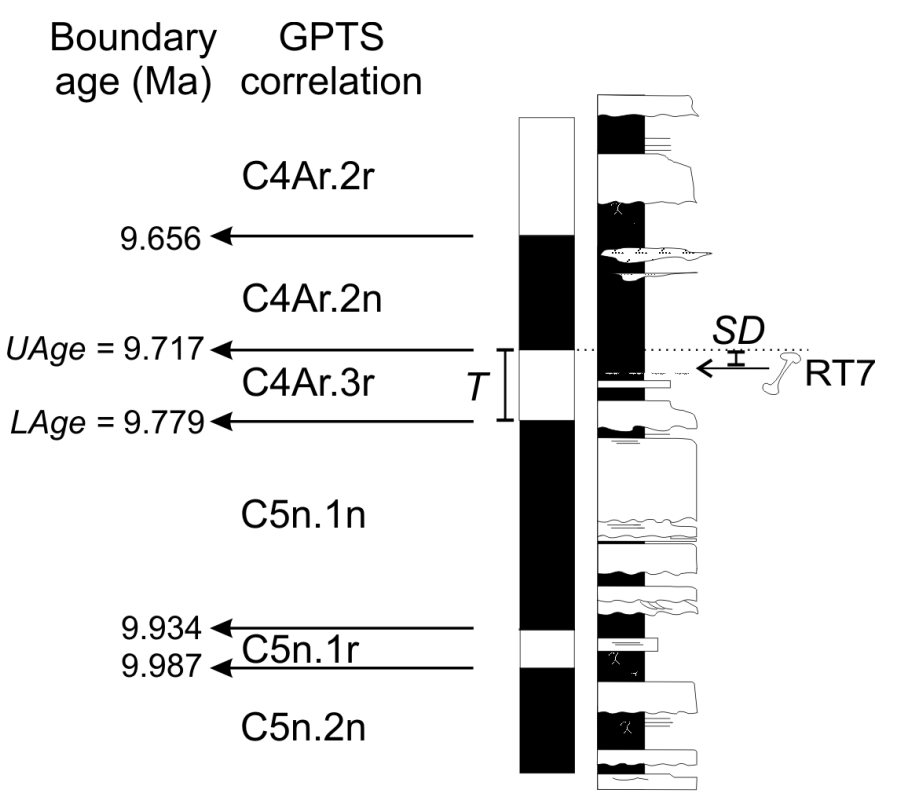

$$
\begin{aligned}
& A g e_{\mathrm{RTT}}=U A g e+\left(\left(\frac{(L A g e-U A g e)}{T}\right) \cdot S D\right) \\
& \mathrm{Age}_{\mathrm{RT7}}=9.717+((0.062 / 12) \cdot 4.4)=9.74
\end{aligned}
$$

Fig. 3.- An example of the method used to assign an absolute age to the localities (after Barry et al., 2002). The position of a locality, in this case RT7 (see table 1), in a local magnetostratigraphical section is shown together with its correlation to the Geomagnetical Polarity Time Scale (GPTS). Age is the estimated absolute age for the locality; UAge and LAge are the ages of the upper and lower boundaries of the geomagnetic chron, respectively; $T$ is the stratigraphic thickness of that magnetozone in the local section; and $S D$ is the stratigraphic distance between the locality and the top of the magnetozone in the same section.

where Age is the estimated absolute age for the locality; UAge and LAge are the ages of the upper and lower boundaries of the geomagnetic chron, respectively; $T$ is the stratigraphic thickness of that magnetozone in the local section; and $S D$ is the stratigraphic distance between the locality and the top of the magnetozone in the same section (Fig. 3). Clearly the term (LAge-UAge)/T equals to the average rate of sedimentation in the section during the geomagnetic chron. Calculations are carried using the local magnetostratigraphical sections, except when one of the chron boundaries is not recorded in the section. In that case the absolute age is calculated using the composite sections which do record the chron boundaries (Fig. 2). For the absolute age of the localities, see Table 1.

Clearly, there is an important underlying assumption of this method: the rate of sediment accumulation within each magnetozone must remain constant. The sites considered in this work are located in medial to distal facies of alluvial fans, where sedimentation is episodic and there are periods of erosion, leading to the existence of many short hiatuses (Sadler, 1981). Therefore, considering the nature of the depositional environment, this basic assumption is clearly violated. However, if no contained hiatus is large relative to the duration of an interval and if the distribution of such hiatuses is random within the stratigraphic sections, these age estimations can be considered adequate (Badgley et al., 1986; Barry et al., 2002). The relative stratigraphic thickness of the same geomagnetic intervals between our local sections is comparable and these sections do not show major hiatuses.

The methods described above can only be used to assign an absolute age to those sites that are placed in magnetostratigraphical sections, which in our case include about half of the sites considered (see Table 1). For the Castell de Barberà site, even though there are no magnetostratigraphical data, the stratigraphical distance to the site of Can Llobateres 1 (placed in the Can Llobateres section) is known to be of 110 m (Crusafont Pairó and Truyols Santonja, 1951), so its absolute age can be estimated taking into account mean accumulation rates for the basin. Garcés (1995) and Garcés et al. (1996) calculated a smooth sedimentation rate of $20 \mathrm{~cm} /$ kyr for the whole basin infill, although they observed that the rate was much higher during the early Vallesian in the more tectonically active basin margin, with rates approaching 100 $\mathrm{cm} / \mathrm{kyr}$. Castell de Barberà is located in the distal facies of the Castellar del Vallès alluvial fan system, so slower accumulation rates should be inferred. Our estimates yield an age of $10.82 \mathrm{Ma}$ if a sedimentation rate of $100 \mathrm{~cm} / \mathrm{kyr}$ is assumed and of $10.27 \mathrm{Ma}$ if one of $20 \mathrm{~cm} / \mathrm{kyr}$ is considered instead. Considering these maximum and minimum possible values, we decided to assign a mean age to that site of $10.55 \mathrm{Ma}$. This places Castell de Barberà within the Hipparion s.1. + Megacricetodon ibericus concurrent range zone, and therefore in the early Vallesian. This site is commonly considered to be late Aragonian in age (see for example Agustí et al., 1999), but De Bruijn et al. (1992) assigned it to the early Vallesian on the basis of the finding of a single Hipparion molar by M. Pickford during a visit to the site with M. Crusafont. In fact, Hipparion had already been reported by Crusafont and Golpe-Posse (1974) and recently Rotgers et al. (2011) figured a Hipparion $\mathrm{m} 3$ found in the collections of this site. Considering the available evidence and taking into account our age estimations, an early Vallesian age for Castell de Barberà seems correct.

With regard to the remaining sites in our database, the correlation is entirely based on biostratigraphical data. Luckily, all the sites can be unambiguously assigned to one of the Vallès-Penedès local zones (for the most recent update, see Casanovas-Vilar et al., 2011a, 2011b), so their age must lie between the top and bottom boundary ages for that particular zone. In their turn, the age of zone boundaries has been established on the basis of magnetostratigraphical data. For these localities, age uncertainty is affected by the duration of the biozone; the shorter the biozone, the higher the resolution. The duration of the biozones ranges between 0.2 and $0.7 \mathrm{my}$, with our first and last zones being the longest ones. Since the age of these localities is poorly constrained and several dif- 


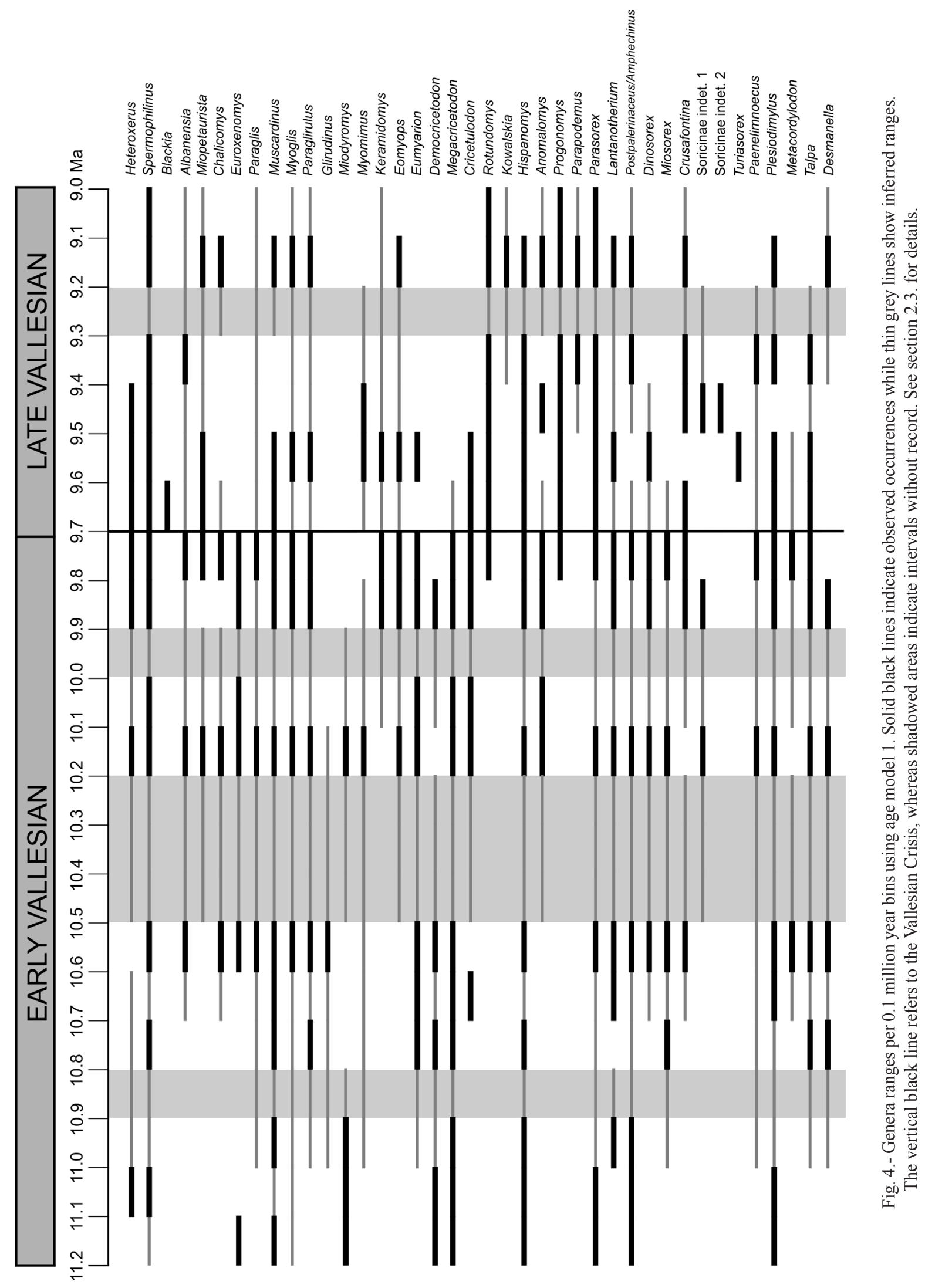




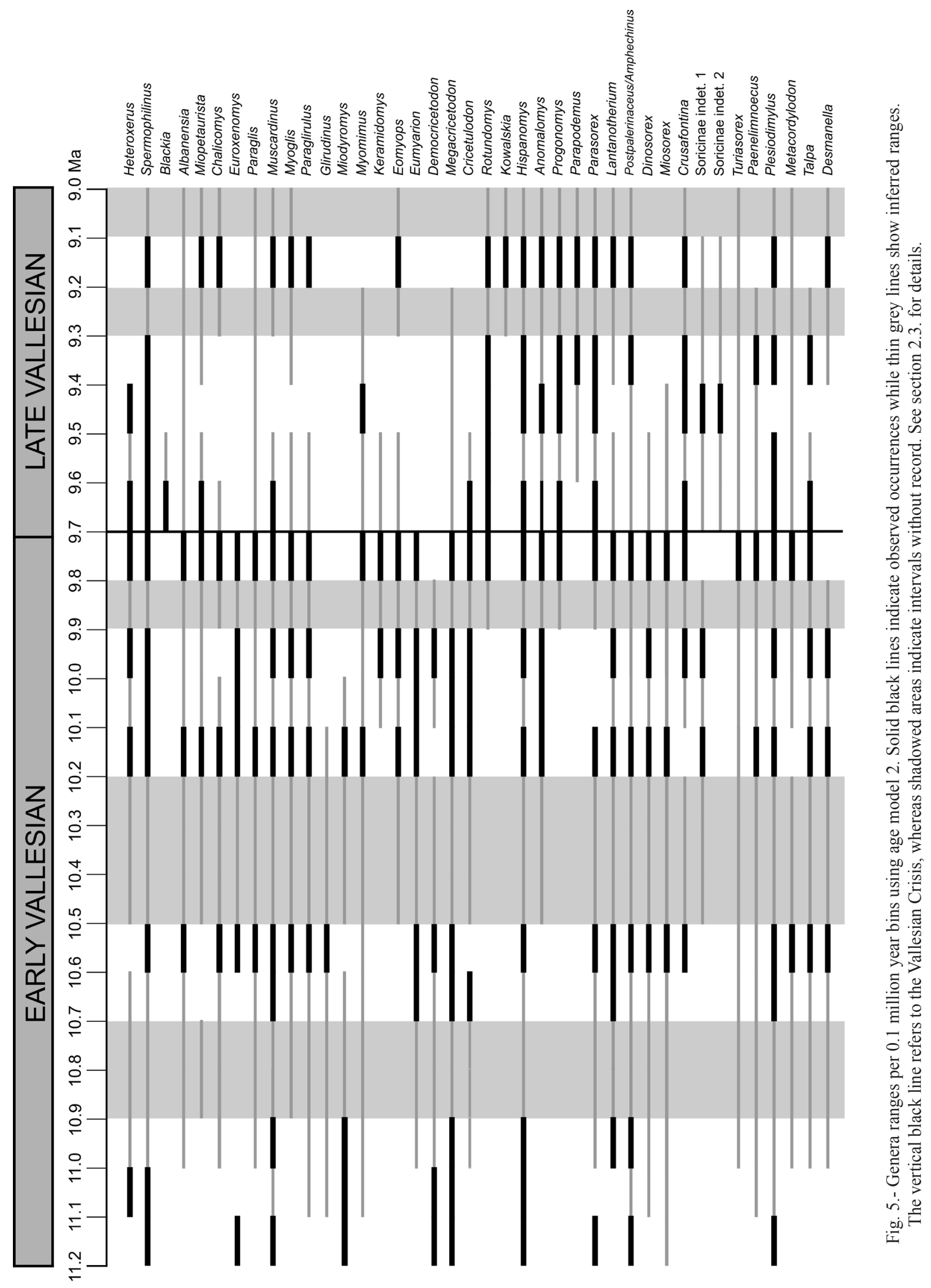




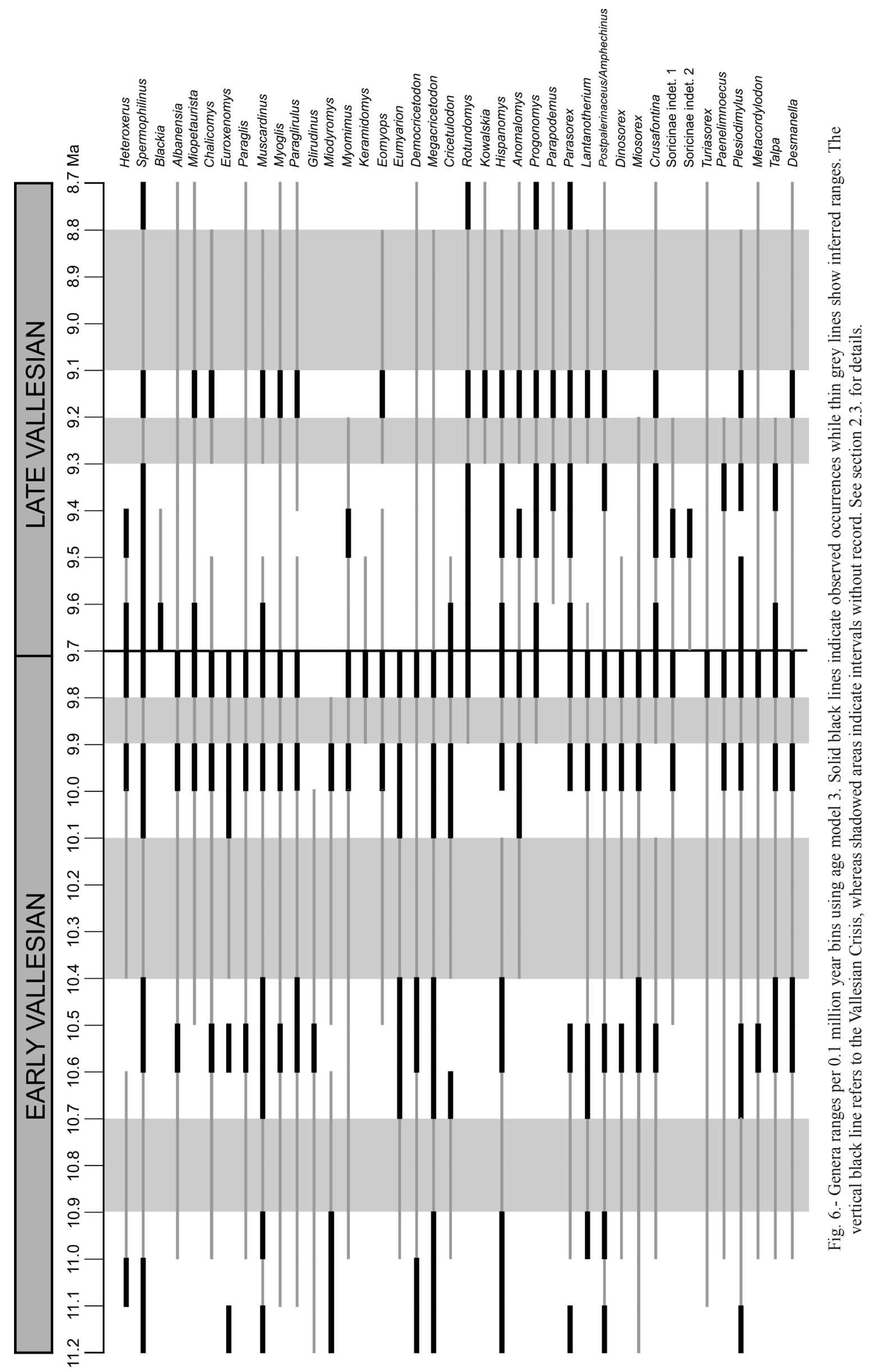




\begin{tabular}{ccccccc}
\hline \multirow{2}{*}{ age model } & \multicolumn{2}{c}{ observed diversity } & \multicolumn{2}{c}{ expected diversity } & \multicolumn{2}{c}{ rarified diversity } \\
\cline { 2 - 7 } & $r_{s}$ & $P$ & $r_{s}$ & $P$ & $r_{s}$ & $P$ \\
\hline age model 1 & 0.897 & $1.52 \cdot 10^{-8 *}$ & -0.349 & 0.11 & 0.343 & 0.27 \\
age model 2 & 0.943 & $5.22 \cdot 10^{-11 *}$ & -0.379 & 0.08 & 0.274 & 0.44 \\
age model 3 & 0.931 & $1.58 \cdot 10^{-11 *}$ & -0.380 & 0.06 & 0.147 & 0.68 \\
\hline
\end{tabular}

Table 2. Spearman's rank order correlation between the different diversity measures and sample size considering different age models. Significant correlations (at $P \leq 0.05$ ) are indicated by *. $r_{s}=$ Spearman's rank order correlation coefficient; $P=$ probability of no correlation.

ferent absolute ages are possible, we have repeated our calculations considering three different age models (Table 1): 1) the age of the locality is calculated as the mean between maximum and minimum age; 2) maximum age is considered; that is the locality is given the age of the lower boundary of the biozone; 3) minimum age is considered; that is the locality is given the age of the upper boundary of the biozone. Our calculations are repeated considering these three age models, and results are compared in order to assess if the assignment of different ages to these poorly constrained localities significantly affects the results.

\subsection{Material, sample size and temporal resolution of the analyses}

The Vallesian record of the Vallès-Penedès basin is very dense for both large and small vertebrates. Terrestrial and freshwater molluscs, such as snails, are present in most sites, whereas plant macrofossils are also known from a handful of localities. Among the vertebrates, reptile and bird fossils are common, but remain mostly unstudied. In contrast, the mammals have been the subject of continuous publications since the very beginning of palaeontological research in the basin. Even though large mammals are well represented in many sites, this study is exclusively focused in the small mammals. Our analyses require the use of abundance data and such information is not available for the large mammals from most sites. In contrast, a record of the abundance of the different small mammal taxa per locality is routinely written down. Among the small mammals, the rodents and insectivores stand out as the most numerous and comprehensively studied mammal orders (for a review and a list of the most relevant systematic papers for rodents see Casanovas-Vilar, 2007 and for insectivores Van den Hoek Ostende and Furió, 2005). Chiropterans are extremely rare finds, whereas lagomorphs are common in most sites, but both orders are left outside of our analyses because their systematic study is still ongoing.

We compiled a quantitative dataset that includes specimen counts of rodents and insectivores from 51 sites of Vallesian age. Such counts derive from published data in some cases, bur mostly are based on unpublished reports. As not all dental elements are taxonomically specific, we counted only the molars and the last premolar. Teeth were counted irrespective of whether isolated or in a mandible. In other words, a mandible with complete toothrow would be counted as 4 (1 last premolar and 3 molars). Since all the insectivores and some rodent families (in our case Sciuridae, Castoridae, Gliridae, Eomyidae) have premolars and others do not (muroid rodents), this results in an over-representation of the former taxa. To avoid this bias some works have considered the number of first and second molars (for example see Daams et al., 1988; Van der Meulen, Daams, 1992; Van Dam, 1997). However, Agustí, Casanovas-Vilar (2007) and CasanovasVilar (2007) already showed that since in most of the sites the muroid rodents define the bulk of the recovered dental remains this way of counting the specimens will have minimal effects on our calculations. The total sample size is of 5,474 cheek teeth belonging to 26 different rodent genera and 14 insectivore ones. The calculations are carried at the genus level for two main reasons: 1) it allows for the inclusion of taxa that are represented by very scarce material, insufficient to identify it to the species level; 2) for an important number of sites comprehensive systematic descriptions have not been published, even though identifications at the genus level are already available. Carrying the calculations out at the genus level has its advantages, but it also limits our conclusions, since our analyses will not be able to elucidate patterns occurring at the species level.

The studied time frame covers the entire Vallesian, which is divided in $0.1 \mathrm{Ma}$ intervals in order to perform our analyses (see section 2.3). Each locality is assigned to a single interval. Given the relatively short studied time span (slightly more than $2 \mathrm{Ma}$ ), $0.1 \mathrm{Ma}$ bins are considered the smallest possible scale of analysis. Similar studies (see for example Barry et $a l ., 2002$ ) have used $0.5 \mathrm{Ma}$ bins, but much longer records of about 6 Ma were studied. Van Dam et al. (2006) also used 0.1 Ma bins in their calculations, which also considered rodents and similar sedimentary environments. Considering that the typical extent of time-averaging for terrestrial vertebrate assemblages in fluvial systems and surface accumulations ranges from 100 to 10,000 years (Behrensmeyer, 1982; Kidwell and Behrensmeyer, 1992), smaller temporal bins do not seem advisable.

Although the Vallesian as a whole is well covered by many sites depending on the age model used (see section 2.1), a few 0.1 time intervals are not represented by any site (see Figs. 3-8). In age model 1, six out of 22 intervals are not represented, whereas in models 2 and 3 the proportion increases to $8 / 22$ and $10 / 25$, respectively. These unrepresented intervals mostly correspond to the first half of the early Vallesian 
and to the latest Vallesian. We must caution that the presence of unsampled intervals will result in the extension of the inferred ranges of some taxa into these time spans. If the unrepresented intervals coincided or followed the Vallesian Crisis, our results would be clearly invalidated, because the range of many taxa that may have disappeared during the crisis would be expanded to successive unsampled intervals, virtually delaying their extinction. Fortunately, this is not the case in our dataset; the time intervals that are thought to coincide with the Vallesian Crisis (9.7-9.6 Ma) and immediately follow it (9.6-9.3) are well represented in all the age models.

\subsection{Calculation of sampling probability and inferred genus ranges}

Estimating the age of appearance and extinction of a given taxon defines one of the main basic goals of paleontology. However, given the very nature and incompleteness of the fossil record, observed ranges will normally be shorter than the true ones. Accordingly, several methods have been developed for calculating confidence intervals on stratigraphic ranges (Strauss and Sadler, 1989; Marshall, 1990, 1997). However, these methods assume that fossiliferous horizons are randomly distributed within the original existence intervals, that fossilization events are independent of each other, and that sampling is continuous or random. Obviously, these assumptions will not hold in our case. Instead of these methods, we have used an approach that calculates the probability of finding a given taxon taking into account its abundance and the sample size. Here, we calculate probability of finding the taxon $(p)$ with the methods devised by Barry et al. (2002) as modified by Van der Meulen et al. (2005) and Van Dam et al. (2006) who consider the following equation:

$$
p=1-(1-q)^{r}
$$

where $q$ is the relative abundance of the taxon in the locality where it was first (or last) recorded and $r$ is the additional numbers of specimens sampled. In contrast to Van Dam et al. (2006), $p$ is not calculated for each locality, but for each 0.1 Ma bin. A genus is considered to be absent when the cumulative probability of finding it over preceding or succeeding intervals is greater than 0.9. In a few cases, a genus is found to disappear from the record and re-appear after some time. In these situations, the genus is assumed to have disappeared from the study area temporally and later reappeared by migration. Inferred genera ranges for the different age models are shown in figures 4-6. Obviously, the inferred appearance of a given taxon may predate its actual first record, and, at the same time, its inferred disappearance may postdate its last record. This is ultimately related to $q$; if the taxon is very rare in the time bin where it is first or last recorded, its inferred range will usually be long, unless the sample size of the succeeding or preceding time bins is large enough to discard that it was actually present.

\subsection{Diversity measures}

Genus diversity is calculated for each $0.1 \mathrm{Ma}$ interval and three different measures are shown for each age model (Figs. 7-9). The first one of these measures is the recorded diversity, that is, the total number of genera recovered at each site without assessing the bias introduced by the quality of the record. This measure is expected to show important fluctuations related to differences in sample size between $0.1 \mathrm{Ma}$ bins rather than reflecting true patterns. Our second diversity measure takes into account the inferred ranges for the different genera and is expected to be less affected by differences in sample size. The same applies to our third diversity measure, rarified diversity, which standardizes our sample size using rarefaction. Rarefaction estimates taxon diversity for a smaller sample than the actual one. The algorithm is taken from Krebs (1989) and calculations have been carried using PAST 2.14 (Hammer et al., 2001). For each age model, we have rarified the sample size of all the bins to a sample size of 100 specimens. For a few time bins (particularly during the earliest and the latest Vallesian), the sample size of the bins is smaller than 100 cheek teeth, so in those cases rarified diversity is not computed. Rarefaction requires a number of conditions: 1) samples should be taxonomically similar and taken from more or less comparable habitats; 2) the collections must have been obtained using standardized sampling procedures (Tipper, 1979). Our data meet both requirements. The rodent and insectivore generic composition in our sites is similar, with only a few additions and absences at particular localities or during certain time intervals, but with no marked differences. All the sites are placed in medial to distal facies of alluvial fan systems, so we can assume that, in a broad sense, the habitat was similar, because the depositional environment is the same for all localities. Finally, the material was recovered using standard screen-washing methods as described in Daams and Freudenthal (1988).

\subsection{Assessing sample size effects}

Figures 7-9 show diversity curves and include a bar-chart representing the sample size (in number of insectivore and rodent cheek teeth) for each $0.1 \mathrm{Ma}$ bin. Unrepresented intervals are shadowed. Even though the bar-charts immediately provide a visual approach that allows evaluating the effects of sample size on diversity measures, Spearman's rank order correlation is used to assess the probability of correlation of the different diversity measures with sample size (Table 2). The calculations are carried using PAST 2.14 (Hammer et al., 2001). For rarified diversity, the intervals with sample sizes below 100 individuals are not considered.

\section{Results}

There is a clear correlation between sample size and recorded diversity, regardless of the age model used (Figs. 7-9 


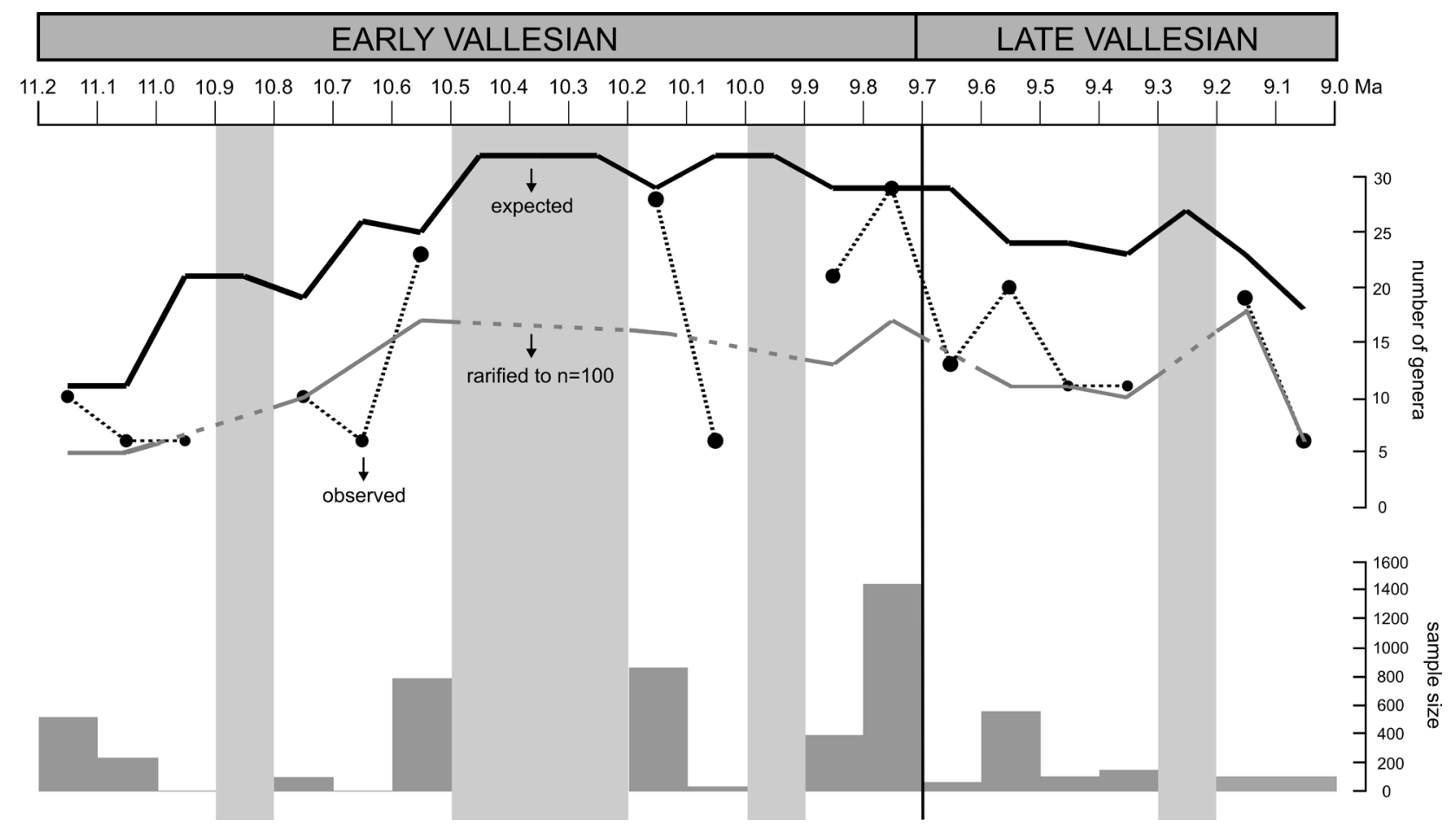

Fig. 7.- Sample size (in number of rodent and insectivore cheek teeth) and diversity measures per 0.1 million year bin using age model 1 . Observed diversity (dashed black line) considers raw specimen counts. Note the coincidence between its peaks and larger sample sizes. Expected diversity (solid black line) considers inferred genera ranges in its calculation. Rarified diversity (solid grey line) shows diversity that would be expected after rarifying sample size per interval to $n=100$ specimens. Rarified diversity could not be calculated for the time bins with a sample size below 100 specimens and this is indicated using a dashed grey line. Shadowed areas indicate intervals without record. See section 2.4. for details.

and Table 2). In all the models, the highest generic diversity is recorded just before the early/late Vallesian boundary, at the 9.8-9.7 Ma interval. After 9.7 Ma, sample size is comparatively much poorer (particularly in age models 2 and 3 ; Figs. 8-9), hence diversity is notably lower. This loss of diversity coincides with the Vallesian Crisis, but our results show that this pattern may clearly be a bias introduced by a marked difference of the quality of the record between the early and late Vallesian. Furthermore, the fact that the time interval that precedes the Vallesian Crisis stands out as the richest one contributes to artificially emphasize the apparent loss of genera, simply because its greater sample size allows recording many rare taxa. Interestingly, all models show quite a high diversity in the 9.2-9.1 Ma interval, by the end of the Vallesian, which is always associated with a small sample size.

When the probability of sampling is taken into account, we can draw the inferred ranges for the rodent and insectivore genera. Figures 4-6 clearly show that many taxa, particularly amongst the sciurids, castorids, glirids and insectivores, are only sporadically recorded. Most of these intermittently present taxa are said to have gone extinct during the Vallesian Crisis (Albanensia, Miopetaurista, Chalicomys, Euroxenomys, Myoglis, Paraglirulus, Eomyops, Keramidomys; see Agustí and Moyà-Solà, 1990; Agustí et al., 1997, 2003), but they are sometimes recorded in certain late Vallesian sites, though they are always rare (see section 4.2). Their intermittent presence during the early Vallesian indicates that they were always rare or highly dependent on local environmental conditions. After the Vallesian Crisis, they continue to be intermittently present, even though they become even rarer. Once we consider the probability of sampling, the gaps in the ranges of most of these genera become continuous, with very few still showing discontinuous distribution (Euroxenomys, Muscardinus and in age models 2 and 3 also Myoglis, Paraglirulus and Eomyops). The inferred ranges of a few genera that are not recorded after the early Vallesian extend into the late Vallesian: Paraglis and Megacricetodon for age model 1; and for age models 2 and 3, the former genera plus Albanensia, Democricetodon, Turiasorex and Metacordylodon. In contrast, the glirids Miodyromys and Glirudinus (always rare components of the rodent assemblages) are found to have disappeared before the Vallesian Crisis.

If inferred ranges are used to calculate generic diversity, the correlation with sample size disappears (Table 2). At the same time, a clear pattern appears in all graphs (Figs. 7-9); diversity rapidly increases during the early Vallesian and peaks between 10.5 and 9.7 Ma (with slight temporal variations depending on the age model considered). After that, diversity decreases during the late Vallesian at a similar rate, showing its minimum at the very last time interval in 


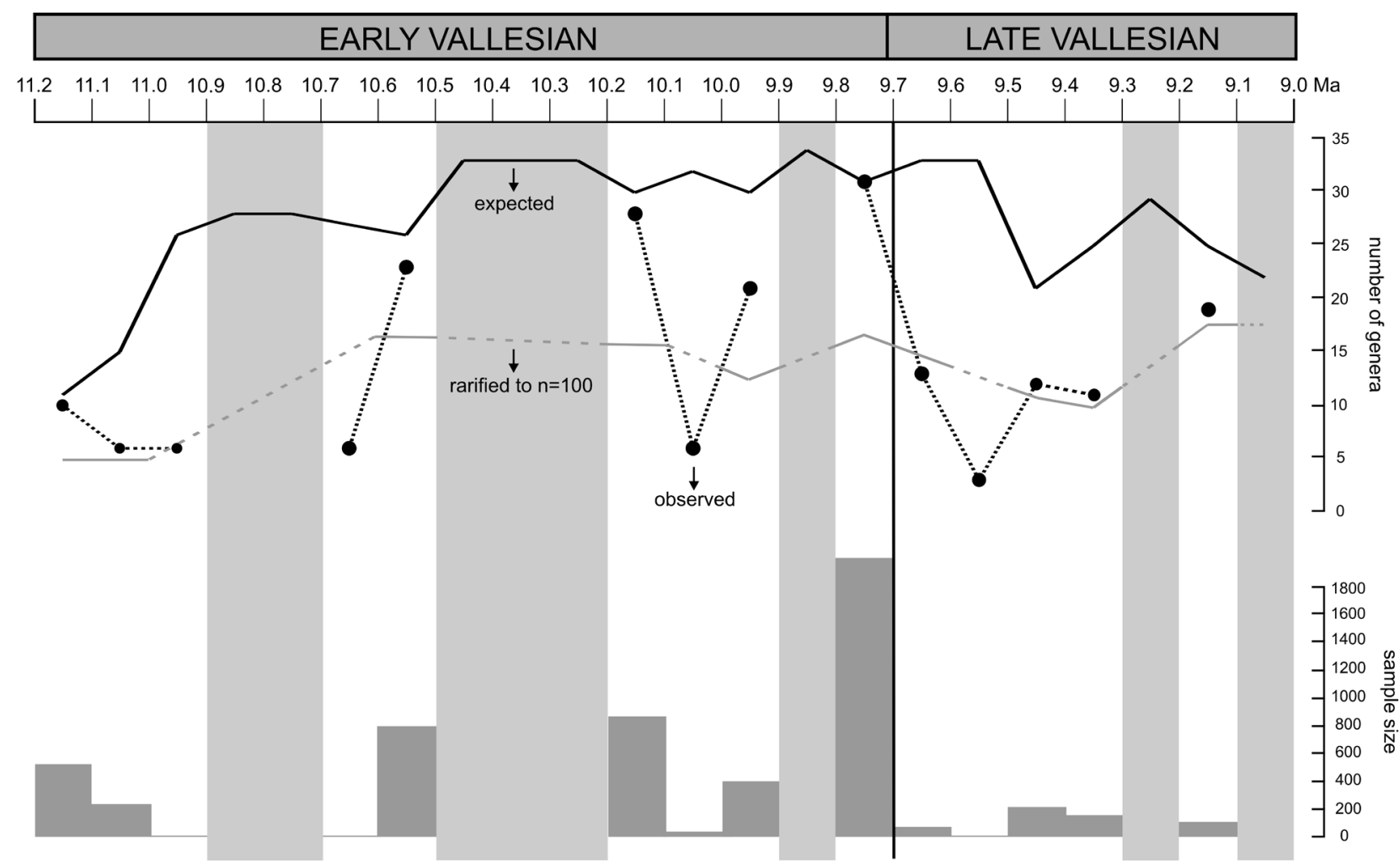

Fig. 8.- Sample size (in number of rodent and insectivore cheek teeth) and diversity measures per 0.1 million year bin using age model 2. Observed diversity (dashed black line) considers raw specimen counts. Note the coincidence between its peaks and larger sample sizes. Expected diversity (solid black line) considers inferred genera ranges in its calculation. Rarified diversity (solid grey line) shows diversity that would be expected after rarifying sample size per interval to $n=100$ specimens. Rarified diversity could not be calculated for the time bins with a sample size below 100 specimens and this is indicated using a dashed grey line. Shadowed areas indicate intervals without record. See section 2.4. for details.

each age model. This reflects the gradual loss of some genera during the late Vallesian, rather than an abrupt diversity collapse. In all models, the paracricetodontid Eumyarion, the castorid Euroxenomys, the sciurid Blackia and the soricids (s. l.) Dinosorex and Miosorex go extinct shortly after the Vallesian Crisis (at about 9.5 Ma). Depending on the model used, other genera disappear by the latest Vallesian, such as the cricetodontids Democricetodon and Megacricetodon, the cricetid Cricetulodon, two undetermined soricid genera and the dimylid Metacordylodon.

Finally, when rarefaction is used to approximate diversity for a sample of 100 individuals, a similar pattern is found for the early Vallesian, with diversity peaking between 10.5 and 9.7 Ma (Figs. 7-9). After 9.7 Ma, our graphs show a moderate decrease in diversity, with generic richness being comparable to that of the earliest Vallesian. Therefore, even though some taxa seem to have disappeared, there is not a marked extinction event at the early/late Vallesian boundary. However, the most interesting pattern of our results using rarified diversity is the marked increase seen in all models at the 9.2-9.1 Ma interval, when this parameter attains its highest values for the whole Vallesian. As we have discussed earlier, such diversity coincides with a relatively small sample size compared to preceding intervals. In all models, diversity markedly decreases as we get closer to the Vallesian/Turolian boundary.

\section{Discussion}

\subsection{Sample size effects on diversity patterns}

Our results clearly show that a raw measurement of smallmammal diversity based on the simple counting of the species present in each locality is inadequate. If diversity is computed in this way, the early Vallesian will always show a much higher diversity than the late Vallesian simply because the sample size is much larger (Figs. 7-9, Table 2). This is even more evident for the time interval that immediately precedes the Vallesian Crisis (9.8-9.7 Ma). This interval comprises Can Llobateres 1 that, with 70 different mammalian species, records the highest diversity during the early Vallesian in all Europe (Madern and Van den Hoek Ostende, 2010). While this pattern may reflect the existence of a true diversity hotspot, it may largely result from the almost continuous excavation of this site for more than 50 years (Crusafont, 1964, Begun et al., 1990; Moyà-Solà and Köhler, 1993, 1995, 1996, Alba et al., 2011a, Alba et al., 2011b). Previous accounts on the severity of the Vallesian Crisis in its type area (Agustí and Moyà-Solà, 1990; Moyà-Solà and Agustí, 1991; Agustí et al., 1997, 1999) have always relied on species counting without correcting for sampling. Unfortunately, the presence of such a marked quality peak immediately inflates diversity as well as origination and extinction rates around to this interval 


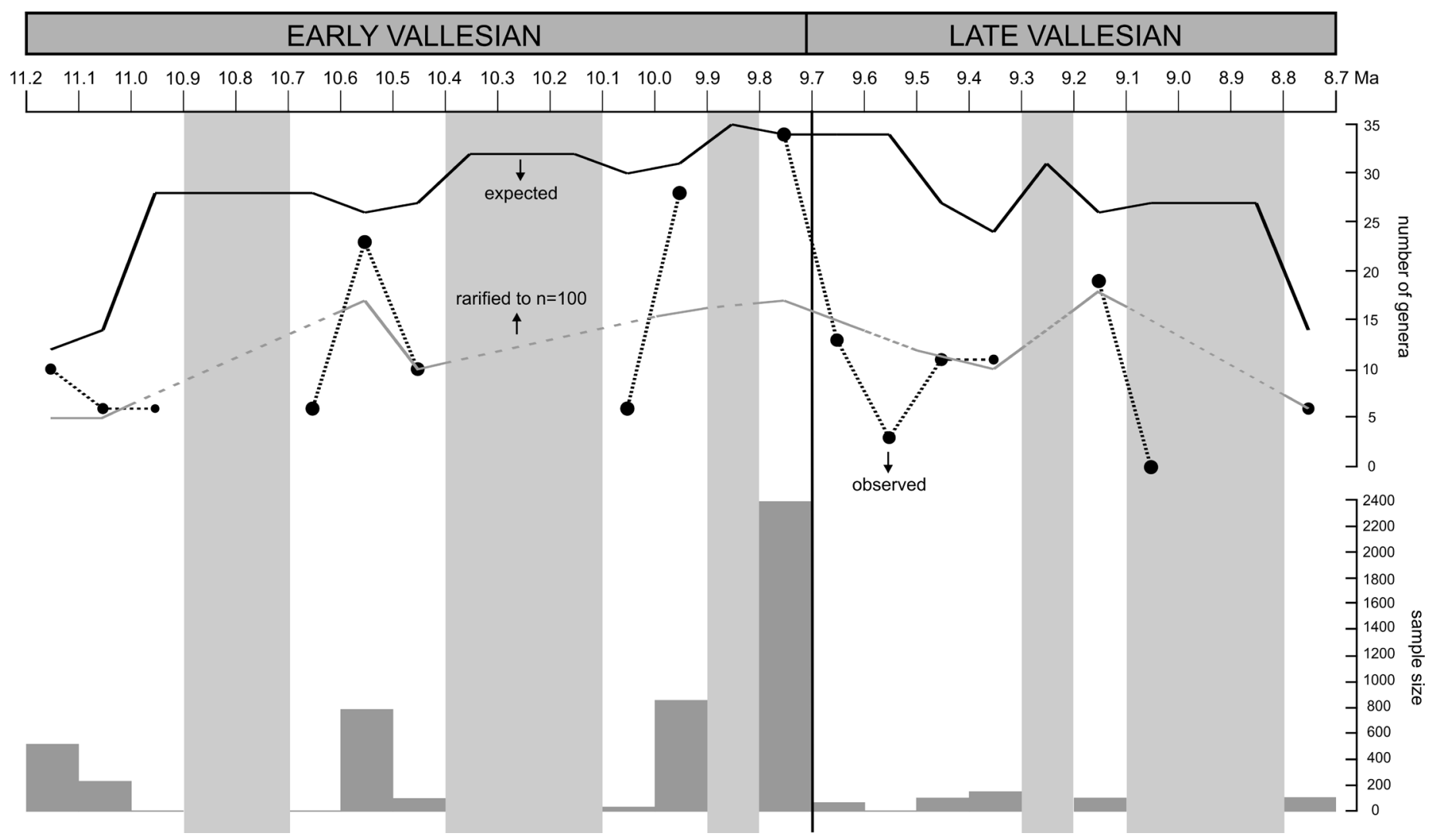

Fig. 9.- Sample size (in number of rodent and insectivore cheek teeth) and diversity measures per 0.1 million year bin using age model 3. Observed diversity (dashed black line) considers raw specimen counts. Note the coincidence between its peaks and larger sample sizes as shown by the histogram. Expected diversity (solid black line) considers inferred genera ranges in its calculation. Rarified diversity (solid grey line) shows diversity that would be expected after rarifying sample size per interval to $n=100$ specimens. Rarified diversity could not be calculated for the time bins with a sample size below 100 specimens and this is indicated using a dashed grey line. Shadowed areas indicate intervals without record. See section 2.4 . for details.

(Foote, 2000). In the case of extinctions, this is because the number of taxa that would have made their last appearance in a preceding interval is then last recorded in the interval with the best record, hence extinction is overestimated after this interval. Clearly this is the case with the Vallesian Crisis, the best sampled interval immediately preceding the event and overemphasizing it.

Then a logical question follows: could these sampling biases affect diversity calculations when all Western Europe is considered? The fact that Can Llobateres 1 appears as a clear diversity hotspot during the early Vallesian (Madern and Van den Hoek Ostende, 2010; see Fig. 10a) suggests so. The results by Fortelius et al. (1996) agree with a severe Vallesian Crisis that would affect Western Europe, while at the same time diversity in Eastern Europe would increase. Later on, Fortelius and Hokkanen (2001) do show a decrease in diversity in all areas except the eastern Mediterranean. This was presumably associated to the demise of small- to mediumsized herbivores and omnivores such as many suoid and cervid species (Fortelius et al., 1996; Fortelius and Hokkanen, 2001) but especially to the disappearance of many small carnivores such as mustelids (Fortelius et al., 1996). These authors record up to 110 large mammal species lost during the Vallesian Crisis, 43 of them carnivores and 20 of them mustelids (Fortelius et al., 1996). This is particularly interesting, since the highest diversity of mustelids during the European Late Miocene is recorded at Can Llobateres 1. This site has yielded up to 13 different mustelid species (Alba et al., 2011b), but five of them are known only from this site (Circamustela dechaseuaxi, Hoplictis petteri, Marcetia santigae, Sabadellictis crusafonti, Trochictis narcisoi). Five more are recorded in this site and a couple of sites more, that in general have also been comprehensively sampled such as Rudabánya or Sansan (Martes mellibulla, Mesomephitis medius, Paralutra sp., Promephitis pristidens, Taxodon cf. sansaniensis). Therefore, would Can Llobateres 1 or other similarly well-sampled early Vallesian sites such as Rudabánya (Hungary) or Götzendorf (Austria) have been removed from the calculations, the pattern would have been different. In figure 10 an equal area grid of cells is projected into Europe and species counts for MN9 within each cell are shown. Figure 10a shows the results including Can Llobateres 1, while in Figure $10 \mathrm{~b}$ this locality is excluded. In the first case there is a clear diversity hot spot coinciding with the Vallès-Penedès basin with 115 different species recorded. This high diversity is followed by the cell covering eastern Austria and western Hungary, where we can find similarly oversampled sites (Götzendorf, Vösendorf). Other diversity hot spots (Teruel 
in Spain, Moldova, eastern Hungary) record a much lower species diversity, between 60 and 90 different species. If Can Llobateres 1 is excluded, the diversity recorded in the Vallès-Penedès decreases to 86 species; still high, but more comparable to that of Teruel and other well-sampled areas of Europe. This simple example, together with our discussion on mustelid diversity, illustrates how the quality of the record for particular sites can affect the calculations if no corrections are applied to diversity measures and how these biases may extend into larger scales. Casanovas-Vilar et al. $(2005,2010)$ computed mean standing diversity (Van Valen, 1984) for the Middle and Late Miocene mammal records of different European regions. This diversity measure excludes the singletons, that is, the taxa known from a single time interval, and in this way somewhat corrects for the different sampling quality. In the case of the Iberian Peninsula, the Vallesian Crisis is still apparent using this measure (Casanovas-Vilar et al., 2010) although it appears to be less marked that using uncorrected data (compare with Casanovas-Vilar et al., 2005) and seems to affect small mammals more severely. A similar, though less marked, decrease in diversity is recorded in Central Europe, but appears to have started by the late Middle Miocene (Casanovas-Vilar et al., 2005; author's unpublished data). A thorough analysis of the geographical extent of the Vallesian Crisis is beyond the goals of this work; nevertheless, our results show that different diversity measures should be used and compared considering quantitative and presence/absence data. As the mustelid example shows, densely-sampled sites such as Can Llobateres 1 can have important effects on the calculations not only at a local, but also at a regional scale. Clearly, any diversity analysis must take into account and assess such biases.

\subsection{Who is missing and when: the victims of the Vallesian Crisis}

According to the latest reviews, the Vallesian Crisis involved the disappearance of most of the Middle Miocene elements adapted to the subtropical and humid forest environments of Western Europe (Agustí et al., 1997, 1999, 2003; Fortelius and Hokannen, 2001; Casanovas-Vilar and Agustí, 2007; Casanovas-Vilar et al., 2005, 2010). The early Vallesian large mammal faunas were characterized by the coexistence for a short time of Middle Miocene forest elements together with a few eastern immigrants, resulting in a diverse, 'supersaturated' fauna. Similarly, the early Vallesian small mammal assemblages contain a diverse number of purported forestdwellers of Middle Miocene origin, but comparatively fewer immigrants (Cricetulodon, Crusafontina). Overall the early Vallesian micromammal faunas are very similar to those of the latest Aragonian (Agustí et al., 1997, 1999; CasanovasVilar, 2007), and do not show increased levels of diversity as seen in the large mammals.

Among the macromammals, the Vallesian Crisis implied the disappearance of several suoids (Listriodon, Albanohy- $u s$ ), carnivores (amphycionids, nimravids), perissodactyls (tapirids, certain rhinocerotids) and, of course, hominoid and pliopithecoid primates (Agustí et al., 1999). As far as small mammals are concerned, lagomorphs and insectivores do not seem to be much affected by the crisis (Agustí and MoyàSolà, 1990), whereas a number of rodent genera are supposed to go extinct (Agustí et al., 1997, 1999, 2003). As said earlier, these include the eomyids (Eomyops, Keramidomys), most of the glirids (Paraglis, Myoglis, Glirudinus, Paraglirulus, Miodyromys), the pteromyines (Miopetaurista, Albanensia), castorids (Euroxenomys, Chalicomys) and certain muroids of Middle Miocene origin (Eumyarion, Democricetodon, Megacricetodon). Our knowledge of the Vallesian record of the Vallès-Penedès basin has greatly improved during the past decades with the discovery of a plethora of new sites. Interestingly, some purported victims of the Vallesian Crisis, such as a number of rodents (Eomyops, Paraglirulus, Myoglis, Chalicomys, Miopetaurista), the boselaphine bovids (Miotragocerus) and even the hominids (Hispanopithecus), have been reported from late Vallesian sites (La Tarumba 1, Torrent de Febulines), even though they are very rare (Agustí et al., 1997; Casanovas-Vilar and Agustí, 2007). A few of these post-crisis occurrences, like that of Hispanopithecus from La Tarumba (= Viladecavalls; Villalta Comella and Crusafont Pairó, 1944), were already known when the Vallesian Crisis was proposed. However, it was supposed that all those taxa disappeared shortly after (Agustí et al., 1997, 1999, 2003).

Amongst the small mammals, the 'victims' of the Vallesian Crisis show a number of common features: 1) they are mostly purported forest-dwellers; 2) they are of Middle Miocene origin; and, more importantly 3) they are rare during the early Vallesian. This third point is worth noting, because these taxa do show a discontinuous distribution, being recorded only in certain sites, usually when sample size is large. The higher diversity recorded in particular early Vallesian time intervals (10.6-10.5 and 9.8-9.7 Ma for all models, besides 10.2-10.1 Ma for models 1 and 2; see Figs. 7-9) is greatly explained by the presence of these rare taxa (compare the diversity curves in those figures with the range charts of figures 4-6). The muroids Eumyarion, Democricetodon and Megacricetodon provide an exception to this general pattern. Megacricetodon ibericus and Democricetodon crusafonti are major components of the earliest Vallesian rodent assemblages $(M$. ibericus + Hipparion s.l. local zone), but both species disappear at about $10.4 \mathrm{Ma}$, that is before the crisis, coinciding with the dispersal of more derived cricetids of the genus $\mathrm{Cri}$ cetulodon (Agustí et al., 1997; Casanovas-Vilar and Agustí, 2007). Other smaller-sized species of those genera, such as M. minor debruijni and D. brevis nemoralis, were far less common, but survived until the late Vallesian. Eumyarion may be very common at particular sites (Castell de Barberà, Can Llobateres 1) and completely absent in others. Therefore, the smaller-sized species of the genera Democricetodon and Megacricetodon as well as the paracricetodontid Eumyarion do show a discontinuous distribution, similar to that 

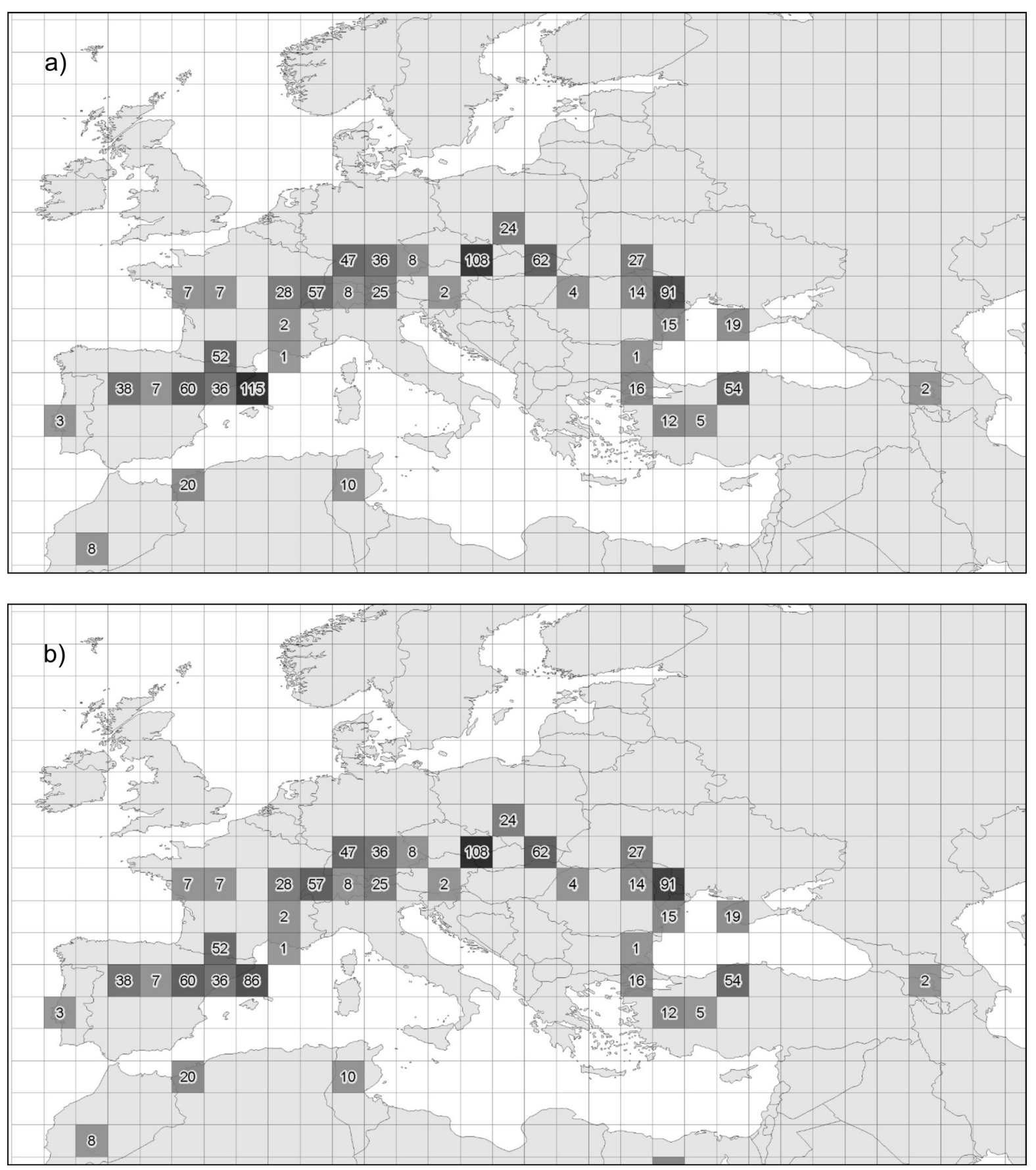

Fig. 10.- Map showing species richness during MN9 (early Vallesian) in Europe. An equal area grid of cells is projected onto the map and species counts within each cell are shown. a) results including Can Llobateres 1; b) results excluding Can Llobateres 1. Note that the exclusion of this site reduces diversity in the Vallès-Penedès basin from 115 to 86 species. Data taken from the NOW database (Fortelius, 2012), dataset downloaded April 2012.

of other 'victims' of the Vallesian Crisis. Such 'victims' are only recovered when sample size is large enough, and, since the sample size of late Vallesian sites is comparatively much smaller than that of the early Vallesian ones, they become virtually absent. Alternatively, these taxa may be highly specialized and associated to specific habitats that are not sampled during the late Vallesian. That may well be the case of beavers, which may be very common in particular sites (Castell de Barberà, Can Llobateres 1), but are mostly absent during the late Vallesian. The evidence provided by sedimentology
(Begun et al., 1990; Agustí et al., 1996; Alba et al., 2011a, 2011b), fresh-water mollusks (Alba et al., 2011a, 2011b) and plant remains (Marmin et al., 2012) are indicative of the presence of shallow lakes and ponds surrounded by dense evergreen vegetation at Can Llobateres 1. Although no taphonomical or sedimentological studies have been published, the same may apply to Castell de Barberà, thus favoring the abundance of castorids there. Interestingly, certain rare dormice, flying squirrels and eomyids are recorded (though not abundant) and Eumyarion is common in these sites, which 
may indicate that these taxa preferred moist forested environments close to water.

Van der Meulen et al. (2005) already noted that the distribution of some rodent taxa was discontinuous in the Calatayud-Daroca basin, in the province of Zaragoza, east-central Spain. These authors analyzed the Miocene rodent record of that area between 17 and $10 \mathrm{Ma}$ and recognized two kinds of community members: residents and transients. Residents are those species that are present along protracted time spans ( $>$ 1.54 million years), whereas transients have shorter durations and are more prone to disappear during times of species loss. Most residents seem to have been ubiquitous taxa or may have been adapted to dry and open environments that characterized the basin for most of the Miocene. In contrast, the transients in the area are supposed specialists favoring humid forested environments. The transients listed by Van der Meulen et al. (2005) include a number of rodent genera that are discontinuously present in the Vallès-Penedès (the Pteromyinae, Microdyromys, Paraglirulus, Glirudinus, Paraglis and Eumyarion). These authors relate the presence of the transients in the Calatayud-Daroca basin to climatic fluctuations allowing the expansion of humid forests in the area during overall dry conditions. On the other hand, many of these transients would be residents in more humid and forested areas of Central Europe, where they are continuously present. It has been shown that during the Vallesian the environment in the Vallès-Penedès basin was more humid and forested than in the inner Iberian basins (Agustí, 1990; Casanovas-Vilar and Agustí, 2007; Casanovas-Vilar et al., 2008), therefore suitable habitats for these transient species would be more common. However, those habitats may have been scarce and patchy or may have been located far from the accumulation areas, so transients would be generally rare or even absent from most sites.

\subsection{An abrupt diversity crisis or a longer turnover event?}

Because the discontinuous distribution of rare taxa is largely related to the uneven nature of the record, their ranges become continuous once sampling probability is taken into account (Figs. 4-6). Then, the inferred ranges of many rare taxa, particularly dormice, flying squirrels and certain insectivores extend into the late Vallesian. The fact that a few of those taxa are actually recorded in a few late Vallesian sites supports the hypothesis that these genera would have survived the Vallesian Crisis and simply would have not been recorded because the sample size is not large enough or the adequate habitats have not been sampled. The use of inferred ranges in our diversity calculations results in the disappearance of the Vallesian Crisis (Figs. 7-9). Diversity decreases by the beginning of the late Vallesian and finally recovers by the end of that period, although diversity levels are never as high as during the latest early Vallesian. If we consider rarified diversity instead, the same pattern emerges (Figs. 7-9), but with diversity peaking late in the Vallesian between 9.2-9.1
Ma! This is because the limited sample size during that time interval records some rare taxa that were not present since the early Vallesian. The causes for this are not understood yet. Maybe the sites in this time interval represent a particular habitat favoring the presence of transients.

Nonetheless, some local extinctions do occur, although not necessarily at the early/late Vallesian boundary. These include the glirids Glirudinus and Miodyromys, the small castorid Euroxenomys and the soricids s.l. Dinosorex and Miosorex. Depending on the model used, the cricetodontids Megacricetodon and Democricetodon, the eomyid Keramidomys and the dimylid insectivore Metacordylodon also go extinct during the late Vallesian. However, whatever the model used, extinctions are relatively few and distributed along all the late Vallesian, rather than clustered at 9.7 Ma. This contrasts with our general understanding of the Vallesian Crisis, since from the earliest papers it was considered to have been an abrupt event occurring at the early/late Vallesian boundary (Agustí and Moyà-Solà, 1990; Moyà-Sola and Agustí, 1991). Subsequent works reported a number of extinctions occurring at the MN 10 (i.e. between 9.7 and $8.7 \mathrm{Ma}$ ), thus supporting that this was a short-lasting event (Fortelius et al., 1996; Agustí et al., 1997, 1999; Fortelius and Hokkanen, 2001; Casanovas-Vilar et al., 2010). According to our results, the disappearance of many micromammal taxa may have been a longer process than shown by the record. The fact that the Vallesian Crisis does not seem to coincide with any significant global climatic event (Van Dam, 2006) is in line with this conclusion.

\section{Conclusions and future prospects}

Our results show that the quality of the record in the VallèsPenedès basin during the latest early Vallesian $(9.8-9.7 \mathrm{Ma})$ is much better than afterwards, so a remarkably high number of rare taxa are recorded. Accordingly, the diversity before the Vallesian Crisis is inflated. On the other hand, extinction rate is overestimated simply because the number of rare taxa that would have made their last appearance in a preceding interval is now last recorded in the interval with the better record. The fact that the best sampled interval immediately precedes the Vallesian Crisis automatically overemphasizes the severity of the event.

Following the use of diversity measures that adjust for sample size biases, the Vallesian Crisis turns into a moderate decrease of diversity with a rapid recovery by the latest Vallesian (9.2-9.1 Ma). This is because it cannot be discarded that several rare taxa said to have disappeared during the crisis are in fact present. Amongst the rodents and insectivores, these taxa include forms that are generally rare and show a discontinuous record during the early Vallesian. These are presumed specialists adapted to humid forested environments such as flying squirrels, beavers or certain dormice, most of them being only recorded when the sample size is large enough. Some of them are de facto present in a few late Vallesian sites, thus supporting our interpretation. Nevertheless, all these taxa ul- 
timately disappear during the Late Miocene, though certainly their extinction does not seem to be a sudden event occurring at $9.7 \mathrm{Ma}$, but during a longer time span.

This work casts doubts on the very existence of this event in the Vallès-Penedès basin as far as rodents and insectivores are concerned. However, could the same biases apply to the large mammal record? A preliminary test on the subject suggests that this could feasibly happen. For example, mustelids are said to be strongly affected by the Vallesian Crisis, losing up to twenty species. But we have shown that this may be strongly influenced by the quality of the record, since ten of these species are known just from one or a couple of sites that have been exhaustively sampled and immediately precede the crisis. Would these sites be removed from our database, the severity of the crisis would reduce by one half. Clearly, any evaluation of the range and extent of the Vallesian Crisis must take into account sample size biases. Additionally, different diversity measures using both abundance and presence/absence data should be used and compared to each other. Ultimately, once these issues are considered the Vallesian Crisis may turn from an abrupt event into a series of Late Miocene extinctions occurring during a longer time span.

\section{Acknowledgements}

First of all we would like to acknowledge the organizers and assistants to the EJIP meetings for their initiative, effort and interest in keeping alive and expanding this nice opportunity for young paleontologists to present their early research. The idea of evaluating how the quality of the record could affect the Vallesian Crisis in its type area was suggested to ICV by his thesis supervisor, Jordi Agustí (IPHES, Universitat Rovira i Virgili, Tarragona) . Furthermore, we are indebted to Jordi for compiling great part of the data on the rodent faunas and for leading most of the previous research on the Vallesian Crisis. We also thank Miguel Garcés (Universitat de Barcelona) for providing data, figures, and valuable discussions on the age of certain Vallesian sites. We deeply acknowledge the reviewers of this manuscript, Mikael Fortelius (University of Helsinki) and Manuel Hernández Fernández (Universidad Complutense de Madrid), who clearly improved the results with their comments and suggestions and further opened new discussions. Finally we would like to acknowledge Albert J. van der Meulen, who was the first one to question the existence of an abrupt diversity crisis in a series of much appreciated discussions with ICV thus introducing some doubts on what we believed to be a 'well-known pattern'. This study has been possible thanks to the support of the Spanish Ministerio de Economía y Competitividad (CGL2011-28681/BTE, CGL2010-21672/BTE, CGL2008-00325/BTE， JC1201008241 to ICV) and the Generalitat de Catalunya (Grup de Recerca Consolidad 2009 SGR 754 of the Agència de Gestió d'Ajuts Universitaris i de Rercerca). AM acknowledges the support given by Leiden University International Study Fund (LISF) and the Alida M. Buitendijk Fund.

\section{References}

Agustí, J. (1981): Roedores Miomorfos del Neógeno de Cataluña. PhD dissertation Universitat de Barcelona: 288 pp.

Agustí, J. (1990): The Miocene rodent succession in Eastern Spain: a zoogeographical appraisal. In: E.H. Lindsay, V. Fahlbusch, P. Mein (eds.), European Neogene Mammal Chronology. Plenum Press, New York: 375-404.

Agustí, J., Casanovas-Vilar, I. (2007): Ecogeographical stability and climate forcing in the Late Miocene (Vallesian) rodent record of Spain. Palaeogeography, Palaeoclimatology, Palaeoecology 248, 169-189. doi: 10.1016/j.palaeo.2006.12.002

Agustí, J., Moyà-Solà, S. (1990): Mammal extinctions in the Vallesian (Upper Miocene). Lecture Notes in Earth Sciences 30/1990, 425-432. doi: 10.1007/BFb0011163

Agustí, J., Moyà-Solà, S. (1991): Spanish Neogene Mammal succession and its bearing on continental biochronology. Newsletters on Stratigraphy 25, 91-114.

Agustí, J., Moyà-Solà, S., Gibert, J. (1984): Mammal distribution dynamics in the eastern margin of the Iberian Peninsula during the Miocene. Paléobiologie Continentale 14, 33-46.

Agustí, J., Köhler, M., Moyà-Solà, S., Cabera, L., Garcés, M. (1996): Can Llobateres: the pattern and timing of the Vallesian hominoid radiation reconsidered. Journal of Human Evolution 31, 143-155. doi: 10.1006/jhev.1996.0055

Agustí, J., Cabrera, L., Garcés, M., Parés, J.M. (1997): The Vallesian mammal succession in the Vallès-Penedès basin (northeast Spain): Paleomagnetic calibration and correlation with global events. Palaeogeography, Palaeoclimatology, Palaeoecology 133, 149-180. doi: 10.1016/S0031-0182(97)00084-9

Agustí, J., Cabrera, L., Garcés, M., Llenas, M. (1999): Mammal turnover and global climate change in the late Miocene terrestrial record of the Vallès-Penedès Basin (NE Spain). In: J. Agustí, L. Rook and P. Andrews (eds.), Hominoid Evolution and climatic change in Europe. Volume 1: The Evolution of Neogene Terrestrial Ecosystems in Europe. Cambridge University Press, Cambridge: 390-412. doi: 10.1017/CBO9780511542329.020

Agustí, J., Sanz de Siria, A., Garcés, M. (2003): Explaining the end of the hominoid experiment in Europe. Journal of Human Evolution 45, 145-153. doi:10.1016/S0047-2484(03)00091-5

Alba, D.M., Casanovas-Vilar, I., Robles, J.M., Marmi, J., Moyà-Solà, S. (2011a): New excavations at the Late Miocene site of Can Llobateres 1 (Vallès-Penedès Basin, NE Iberian Peninsula): preliminary results of the 2010 field campaign. In: A. Pérez-García, F. Gascó, J.M. Gasulla, F. Escaso (eds.), Viajando a Mundos Pretéritos. Ayuntamiento de Morella, Morella: 35-43.

Alba, D.M., Casanovas-Vilar, I., Moyà-Solà, S., Robles, J.M. (2011b): Parada 4. El Vallesiense inferior y su transición con el Vallesiense superior: Can Llobateres. In: M. Pérez de los Ríos, J. Marigó, R. Minwer-Barakat, A. Bolet, D. DeMiguel (eds.), Guía de Campo XXVII Jornadas de la Sociedad Española de Paleontología. Paleontologia i Evolució memòria especial 6, Institut Català de Paleontologia Miquel Crusafont, Sabadell: 111-123.

Badgley, C., Tauxe, L., Bookstein, F.L. (1986): Estimating the error of age interpolation in sedimentary rocks. Nature 319, 139-141. doi: 10.1038/319139a0

Barry, J.C., Morgan, M.E., Flynn, L.L., Pilbeam, D., Behrensmeyer, A.K., Mahmood Raza, S., Khan, I.A., Badgley, C., Hicks, J., Kelley, J. (2002): Faunal and environmental change in the Late Miocene Siwaliks of Northern Pakistan. Paleobiology Memoirs 3 (volume 28, supplement to number 2), 1-71. doi: 10.1666/0094-8373(2002)28[1:FA ECIT]2.0.CO;2

Barrón, E., Rivas-Carballo, R., Postigo-Mijarra, J.M., Alcalde-Olivares, C., Vieira, M., Castro, L., Pais, J., Valle-Hernández, M. (2010): The 
Cenozoic vegetation of the Iberian Peninsula: a synthesis. Review of Palaeobotany and Palynology 162, 382-402. ne 2 December 2009. doi: 10.1016/j.revpalbo.2009.11.007

Begun, D.R., Moyà-Solà, S., Köhler, M. (1990): New Miocene hominoid specimens from Can Llobateres (Vallès Penedès, Spain) and their geological and paleoecological context. Journal of Human Evolution 19, 255-268. doi: 10.1016/0047-2484(90)90068-M

Behrensmeyer, A.K. (1982): Time resolution in fluvial vertebrate assemblages. Paleobiology 8, 211-227.

Böhme, M., Ilg, A., Winklhofer, M. (2008): Late Miocene "washhouse" climate in Europe. Earth and Planetary Science Letters 275, 393-401.

doi:10.1016/j.epsl.2008.09.011

Casanovas-Vilar, I. (2007): The rodent assemblages from the Late Aragonian and the Vallesian (Middle to Late Miocene) of the Vallès-Penedès basin (Catalonia, Spain). $\mathrm{PhD}$ dissertation Universitat Autònoma de Barcelona: 286 pp. http://www.cbm.uam.es/sev/Rodents.pdf

Casanovas-Vilar, I., Agustí, J. (2007): Ecogeographical stability and climate forcing in the Late Miocene (Vallesian) rodent record of Spain. Palaeogeography, Palaeoclimatology, Palaeoecology 248, 169-189. doi:10.1016/j.palaeo.2006.12.002

Casanovas-Vilar, I., Moyà-Solà, S., Agustí, J., Köhler, M. (2005): The geography of a faunal turnover: tracking the Vallesian Crisis. In: A.M.T. Elewa (ed.), Migration of Organisms. Climate, Geography, Ecology. Springer, Heidelberg: 247-300.

Casanovas-Vilar, I., Alba, D.M., Moyà-Solà, S., Galindo, J., Cabrera, L., Garcés, M., Furió, M., Robles, J.M., Köhler, M., Angelone, C. (2008): Biochronological, taphonomical and paleoenvironmental background of the fossil great ape Pierolapithecus catalaunicus (Primates, Hominidae). Journal of Human Evolution 55; 589-603. doi:10.1016/j. jhevol.2008.05.004

Casanovas-Vilar, I., García-Paredes, I., Alba, D.M., Van den Hoek Ostende, L.W., Moyà-Solà, S. (2010): The European Far West: Miocene mammal isolation, diversity and turnover in the Iberian Peninsula. Journal of Biogeography 37, 1079-1093. doi: 10.1111/j.1365-2699.2010.02286.x

Casanovas-Vilar, I., Alba, D.M., Garcés, M., Robles, J.M., Moyà-Solà, S. (2011a): Updated chronology of the Miocene hominoid radiation in Western Eurasia. Proceedings of the National Academy of Sciences of the USA 108, 5554-5559. doi: 10.1073/pnas.1018562108

Casanovas-Vilar, I., Alba, D.M., Robles, J.M. (2011b): Registro paleontológico continental del Mioceno de la cuenca del Vallès-Penedès. In: M. Pérez de los Ríos, J. Marigó, R. Minwer-Barakat, A. Bolet, D. DeMiguel (eds.), Guía de Campo XXVII Jornadas de la Sociedad Española de Paleontología. Paleontologia i Evolució memòria especial 6, Institut Català de Paleontologia Miquel Crusafont, Sabadell: 55-80.

Crusafont Pairó, M. (1950): La cuestión del llamado Meótico español. Arrahona 1, 41-48.

Crusafont Pairó, M., Truyols Santonja, J. (1951): Hallazgo del Plesiodimylus chantrei Gaillard en el Meótico del Vallés. Notas y Comunicaciones del Instituto Geológico y Minero de España 22, 3-30.

Crusafont, M. (1964): La biota de Can Llobateres (Sabadell) y su significación paleobiológica. Cursillos y Conferencias del Instituto "Lucas Mallada" 9, 177-179.

Crusafont, M., Golpe-Posse, J.M. (1974): Nuevos yacimientos del Terciario continental del N.E. de España. Acta Geológica Hispánica 9, 81-83.

Daams, R., Freudenthal, M. (1988): Synopsis of the Dutch-Spanish collaboration program in the Aragonian type area, 1975-1986. Scripta Geologica special issue 1, 3-18.

Daams, R., Freudehthal, M., Van der Meulen, A.J. (1988): Ecostratigraphy of micromammal faunas from the Neogene of the CalatayudTeruel Basin. Scripta Geologica special issue 1, 287-302.

De Bruijn, H., Daams, R., Daxner-Höck, G., Fahlbusch, V., Ginsburg,
L., Mein, P., Morales, J. (1992): Report of the RCMNS working group on fossil mammals Reisenberg 1990. Newsletters on Stratigraphy 26, 65-118.

De Bruijn, H., Ünay, E., Van den Hoek Ostende, L.W. (1996): The composition and diversity of small mammal associations from Anatolia through the Miocene. In: R.L. Bernor, V. Fahlbusch, H.-W. Mittmann (eds.), The Evolution of Western Eurasian Neogene Mammal Faunas. Columbia University Press, New York: 266-270.

Foote, M. (2000): Origination and extinction components of taxonomic diversity: general problems. Paleobiology 26 supplement: 74-102. doi: 10.1666/0094-8373(2000)26[74:OAECOT]2.0.CO;2

Fortelius, M. (coordinator) (2012): New and Old Worlds Database of Fossil Mammals (NOW). University of Helsinki. http://www.helsinki.fi/science/now/

Fortelius, M., Hokkanen, A. (2001): The trophic context of hominoid occurrence in the later Miocene of western Eurasia: a primate-free view. In: L. de Bonis, G.D. Koufos, P. Andrews (eds.), Hominoid Evolution and climatic change in Europe. Volume 2: Phylogeny of Neogene Primates of Eurasia. Cambridge University Press, Cambridge: 19-47. doi: 10.1017/CBO9780511600449.002

Fortelius, M., Werdelin, L., Andrews, P., Bernor, R.L., Gentry, A., Humphrey, L., Mittmann, H.-W., Virantana, S. (1996): Provinciality, diversity, turnover and paleoecology in land mammal faunas of the later Miocene of Western Eurasia. In: R.L. Bernor, V. Fahlbusch, H.-W. Mittmann (eds.), The Evolution of Western Eurasian Neogene Mammal Faunas. Columbia University Press, New York: 414-448.

Franzen, J.L., Storch, G. (1999): Late Miocene mammals from Central Europe. In: J. Agustí, L. Rook and P. Andrews (eds.), Hominoid Evolution and climatic change in Europe. Volume 1: The Evolution of Neogene Terrestrial Ecosystems in Europe. Cambridge University Press, Cambridge: 165-190. doi: 10.1017/CBO9780511542329.009

Galobart, A., Acosta, C.A., Vila, B. (2011): Patrocinio y mecenazgo en paleontología de vertebrados: Crusafont, Hürzeler y Can Llobateres, diez años de una colaboración inacabada. In: J. Marigó, M. Pérez de los Ríos, R. Minwer-Barakat, D. DeMiguel, A. Bolet (eds.), XXVII Jornadas de la Sociedad Española de Paleontología. Simposios de los proyectos PICG 587 y 596. Paleontologia i Evolució memòria especial 5, Institut Català de Paleontologia Miquel Crusafont, Sabadell: 151-156.

Garcés, M. (1995): Magnetoestratigrafía de las sucesiones del Mioceno Medio y Superior del Vallès Occidental (Depresión del VallèsPenedès, N.E. España). Unpublished PhD dissertation, Universitat de Barcelona: $337 \mathrm{pp}$.

Garcés, M., Agustí, J., Cabrera, L., Parés, J.M. (1996): Magnetostratrigraphy of the Vallesian (late Miocene) in the Vallès-Penedès Basin (northeast Spain). Earth and Plannetary Science Letters 142, 381396. doi: 10.1016/0012-821X(96)00110-0

Gómez Gras, D., Parcerisa, D., Calvet, F., Porta, J., Solé de Porta, N. (2001): Stratigraphy and petrology of the Miocene Montjuïc delta (Barcelona, Spain). Acta Geológica Hispánica 36, 115-136.

Hammer, Ø, Harper, D.A.T., Ryan, P. (2001): PAST: Paleontological statistics software package for education and data analysis. Paleontologia Electronica, 4 (1, art. 4), 9 pp.

Kidwell, S.M., Behrensmeyer, A.K., eds. (1993): Taphonomic approaches to time resolution in fossil assemblages. The Paleontological Society, Knoxville: 303 pp.

Krebs, C.J. (1998): Ecological Methodology. $2^{\text {nd }}$ ed. Addison-Wesley Educational Publishers, Boston: 624 pp.

Lindsay, E.H., Tedford, R. (1990): Development and application of Land Mammal Ages in North America and Europe, a comparison. In: E.H. Lindsay, V. Fahlbusch, P. Mein (eds.), European Neogene Mammal Chronlogy. Plenum Press, New York: 601-624.

Madern, A., Van den Hoek Ostende, L.W. (2010): Drift in Miocene mammalian biodiversity hotspots along a latitudinal gradient. Zitteliana B29, 72. 
Marmi, J.M., Casanovas-Vilar, I., Robles, J.M., Moyà-Solà, S., Alba, D.M. (2012): The paleoenvironment of Hispanopithecus laietanus as revealed by paleobotanical evidence from the Late Miocene of Can Llobateres 1 (Catalonia, Spain). Journal of Human Evolution 62, 412423. doi:10.1016/j.jhevol.2011.12.003

Marshall, C.R. (1990): Confidence intervals on stratigraphic ranges. $\mathrm{Pa}$ leobiology 16, 1-10.

Marshall, C.R. (1997): Confidence intervals on stratigraphic ranges with nonrandom distribution of fossil horizons. Paleobiology 23, 165-173.

Mein, P. (1975): Résultats du Groupe de Travail des Vertébrés. In: J. Senes (ed.), Report on Activity of the RCMNS Working Groups - 6 . Congress of the Regional Committee of Mediterranean Neogene Stratigraphy, Proceedings 1. Bratislava: 78-81.

Mossbrugger, V., Utescher, T., Dilcher, D.L. (2005): Cenozoic climatic evolution of Central Europe. Proceedings of the National Academy of Sciences USA 102, 14964-14969. doi: 10.1073/pnas.0505267102

Moyà-Solà, S., Agustí, J. (1987): The Vallesian in the type area (VallèsPenedès, Barcelona, Spain). Annales Instituti Geologici Publici Hungarici 70, 93-99.

Moyà-Solà, S., Agustí, J. (1990): Bioevents and mammal successions in the Spanish Miocene. In: E.H. Lindsay, V. Fahlbusch, P. Mein (eds.), European Neogene Mammal Chronlogy. Plenum Press, New York: 357-373.

Moyà-Solà, S., Köhler, M. (1993): Recent discoveries of Dryopithecus shed new light on evolution of great apes. Nature 365, 543-545. doi:10.1038/365543a0

Moyà-Solà, S., Köhler, M. (1995): New partial cranium of Dryopithecus Lartet, 1863 (Hominoidea, Primates) from the upper Miocene of Can Llobateres, Barcelona, Spain. Journal of Human Evolution 29, 101139. 02. doi: 10.1006/jhev.1995.1049

Moyà-Solà, S., Köhler, M. (1996): A Dryopithecus skeleton and the origins of great-ape locomotion. Nature 379, 156-159. doi:10.1038/379156a0

Moyà-Solà, S., Köhler, M., Alba, D.M., Casanovas-Vilar, I., Galindo, J., Robles, J.M., Cabrera, L., Garcés, M., Almécija, S., Beamud, E. (2009a): First partial face and upper dentition of the Middle Miocene hominoid Dryopithecus fontani from Abocador de Can Mata (VallèsPenedès Basin, Catalonia, NE Spain): taxonomic and phylogenetic implications. American Journal of Physical Anthropology 139, 126145. doi: 10.1002/ajpa.20891

Ogg, J.G, Smith, A.G. (2004): The geomagnetic polarity time scale. In: F.M. Gradstein, J.G. Ogg, A.G Smith (eds.), A Geologic Time Scale 2004. Cambridge University Press, Cambridge: 63-86.

Rotgers, C., Alba, D.M. (2011): The genus Anchitherium (Equidae: Anchitheriinae) in the Vallès-Penedès Basin (Catalonia, Spain). In: A. Pérez-García, F. Gascó, J.M. Gasulla, F. Escaso (eds.), Viajando a Mundos Pretéritos. Ayuntamiento de Morella, Morella: 347-354.
Sadler, P.M. (1981): Sediment accumulation rates and the completeness of stratigraphic sections. Journal of Geology 89, 569-584.

Strauss, D., Sadler, P.M. (1989): Classical confidence intervals and Bayesian probability estimates for ends of local taxon ranges. Mathematical Geology 21, 411-427. doi: 10.1007/BF00897326

Tipper, J.C. (1979): Rarefaction and rarefiction - the use and abuse of a method in paleoecology. Paleobiology 5, 285-307.

Van Dam, J.A. (1997): The small mammals from the Upper Miocene of the Teruel-Alfambra region (Spain): paleobiology and paleoclimatic reconstructions. Geologica Ultraiectina 156, 4-204.

Van Dam, J.A. (2006). Geographic and temporal patterns in the late Neogene (12-3 Ma) aridification of Europe: The use of small mammals as paleoprecipitation proxies. Palaeogeography, Palaeoclimatology, Palaeoecology 238, 190-218. doi: 10.1016/j.palaeo.2006.03.025

Van Dam, J.A., Weltje, G.J. (1999): Reconstruction of the late Miocene climate of Spain using rodent paleocommunity successions: an application of end-member modelling. Palaeogeography, Palaeoclimatology, Palaeoecology 151, 267-305. doi: 10.1016/S00310182(99)00015-2

Van Dam, J.A., Alcalá, L., Alonso-Zarza, A., Calvo, J.P., Garcés, M., Krijgsman, W. (2001): The upper Miocene mammal record from the Teruel Alfambra region (Spain). The MN system and continental stage/age concepts discussed. Journal of Vertebrate Paleontology 21, 367-385. doi: 10.1671/0272-4634(2001)021[0367:TUMMRF]2.0 . $\mathrm{CO} ; 2$

Van Dam, J.A., Abdul Aziz, H., Álvarez Sierra, M.A., Hilgen, F.J., Van den Hoek Ostende, L.W., Lourens, L.J., Mein, P., Van der Meulen, A.J., Pélaez-Campomanes, P. (2006): Long-period astronomical forcing of mammal turnover. Nature 443, 687-691. doi: 10.1038/nature 05163

Van den Hoek Ostende, L., Furió, M. (2005): Spain. Scripta Geologica special issue 5, 149-356.

Van der Meulen, A.J., Daams, R. (1992): Evolution of Early-Middle Miocene rodent faunas in relation to long-term palaeoenvironmental changes. Palaeogeography, Palaeoclimatology, Palaeoecology 93, 227-253. doi: 10.1016/0031-0182(92)90099-Q

Van der Meulen, A.J., Pélaez-Campomanes, P., Levin, S.A. (2005): Age estructure, residents, and transients of Miocene rodent communities. The American Naturalist 165, E108-E125. doi: 00030147/2005/16504-40766\$15.00

Van Valen, L.M. (1984): A resetting of Phanerozoic community evolution. Nature 307, 50-52. doi:10.1038/307050a0.

Villalta Comella, J.F. de, Crusafont Pairó, M. (1944): Dos nuevos antropomorfos del Mioceno español y su situación dentro de la moderna sistemática de los símidos. Notas y Comunicaciones del Instituto Geológico y Minero de España 13, 1-51.

Zachos, J., Pagani, M., Sloan, L., Thomas, E., Billups, K. (2001): Trends, rhythms and aberrations in global climate 65 Ma to present. Science 292, 686-693. doi: 10.1126/science.1059412 